\title{
Petrography of Radioactive
}

Tertiary Igneous Rocks

\section{Front Range Mineral Belt} Colorado

G EOL O G I C A L S U R V E Y B U L L E T I N 1032 - E

Prepared on behalf of the United States Atomic Energy Commission and published with the permission of the Commission

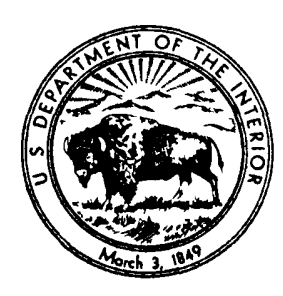




\section{Petrography of Radioactive}

Tertiary Igneous Rocks

Front Range Mineral Belt

\section{Colorado}

By J. D. WELLS

GEOLOGY AND ORE DEPOSITS OF CLEAR CREEK, GILPIN, AND LARIMER COUNTIES, COLORADO

GEOLOGICAL S URVEY B ULLE T IN $1032-\mathrm{E}$

Prepared on behalf of the United States Atomic Energy Commission and published with the permission of the Commission

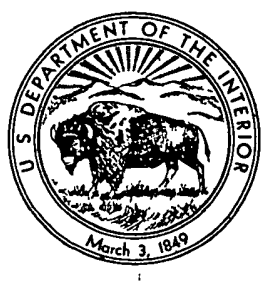




\title{
UNITED STATES DEPARTMENT OF THE INTERIOR \\ FRED A. SEATON, Secretary
}

\author{
GEOLOGICAL SURVEY
}

Thomas B. Nolan, Director 


\section{CONTENTS}

\begin{tabular}{|c|c|}
\hline \\
\hline Abstract & \\
\hline Introduction & \\
\hline & \\
\hline & \\
\hline - & \\
\hline internal structures & \\
\hline 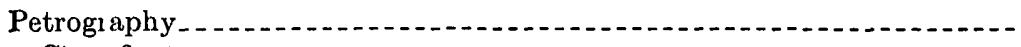 & \\
\hline ( & \\
\hline 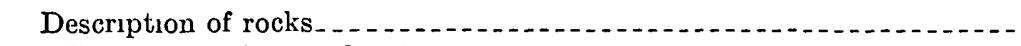 & \\
\hline odiorite group & \\
\hline e porphyry & \\
\hline yry & \\
\hline 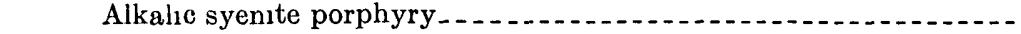 & \\
\hline - & \\
\hline ry & \\
\hline & \\
\hline - & \\
\hline & \\
\hline rous bostonite porphyry & \\
\hline - & \\
\hline 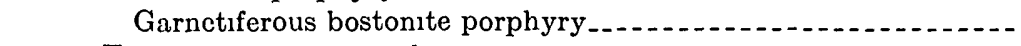 & \\
\hline (2n-1 & \\
\hline 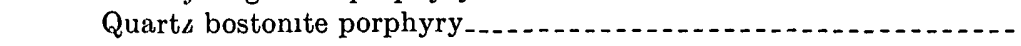 & \\
\hline p. & \\
\hline orphyry & \\
\hline yry & \\
\hline rphyry & \\
\hline 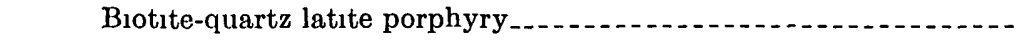 & \\
\hline & \\
\hline 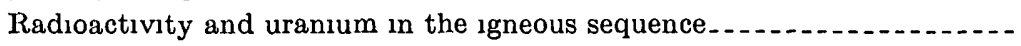 & \\
\hline ( & \\
\hline 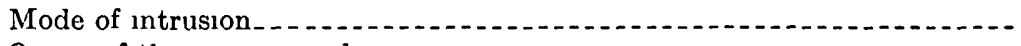 & \\
\hline - & \\
\hline d thoriu & \\
\hline 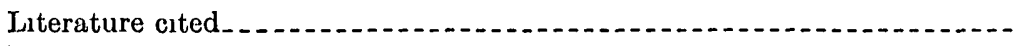 & \\
\hline & \\
\hline
\end{tabular}




\section{ILLUSTRATIONS}

Plate 19 Geologic map showing the Tertıary igneous rocks........... In pocket

Figure 57 Index map of the Front Range, Colorado

58 Diagram showing the probable sequence of intrusion of the

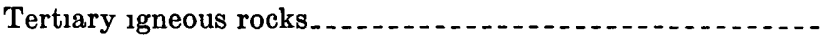

59 Histograms showing distribution of radioactivity (equivalent uranium) and uranium in all Tertiary rocks

60 Histograms showing distribution of radioactivity (equivalent uranıum) uranıum in the hornblende granodiorite group ....

61 Histograms showing distribution of radioactivity (equivalent uranıum) and uranıum in the light-colored granodiorite

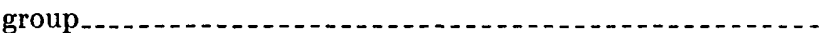

62 Histograms showing distribution of radioactivity (equivalent uranıum) and uranium in the quartz monzonite group......

63 Histograms showing distribution of radioactivity (equivalent uranium) and uranium in the bostonite group..............

64. Diagram showing variations of equivalent uranium (radioactivity) and uranium with rock type arranged in order of de-

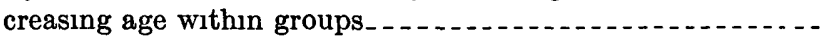

65. Diagram showing variation of equivalent uranium (radioactivity) and uranium with rock type and time............

\section{TABLE}

TABLE 1 Petrographic characteristics of the Tertiary igneous rocks_...- 


\title{
GEOLOGY AND ORE DEPOSITS OF CLEAR CREEK, GILPIN, AND LARIMER COUNTIES, COLORADO
}

\section{PETROGRAPHY OF RADIOACTIVE TERTIARY IGNEOUS ROCKS, FRONT RANGE MINERAL BELT, COLORADO}

\author{
By JoHN D. WeLLS
}

\begin{abstract}
The cential pait of the Front Range mineial belt, an area of Precambiıan metamoıphic and igneous rocks, was intruded during early Teitiary tıme by small 11 egular plutons and dikes of radioactive porphyıitıc rocks Two of the lock types repiesented, bostonite porphyry and quaitz bostonite porphyıy, are highly radioactive

These Teitiaiy igneous rocks have several characteristics in common The groundmass of the porphyıles is generally vely fine grained feldspar and quartz The phenociysts lange in grain fiom coarse to medium and range in quantity fiom abundant to sparse The most common phenocrysts are one or more of the plaglioclase or potassic feldspars, phenociysts of ferromagnesian mineials are common though not always present; qualtz and garnet phenocrysts occur The rocks are generally altered

The poiphyıtıc rocks, which consist of 13 mappable units, can be classified accolding to petrographic similarities into 4 gi oups These gi oups are the lightcolored gianodiorite gioup which includes the light-colored granodionite porphyry, albite gianodiorite porphyry, and alkalic syenite porphyry, the quaitz monzonite gloup which includes the quartz monzonite porphyry, granite porphyry, and alaskite poiphyry, the bostonite gioup which includes the bostonite poiphyry, trachytic granite porphyry, and quartz bostonite porphyry, and the hornblende gianodiorite group which includes the hoinblende granodion ite poiphyry, biotite granodionte porphyry, biotite-quaitz monzonite porphyı, and biotite-quartz latite porphyry.

The bostonite gioup has a distinctive trachytic or bostonitic texture, contains abundant alkalıc minerals, is characterıstically reddish brown to "lilac", and may contain aegirine-augite The other groups have a granular textuie and are geneially gray The light-colored granodiorite gloup contains abundant albite and sparse aegirne-augite(?) The quaitz monzonite gioup contains abundant quartz in the groundmass, abundant oligoclase and potassic feldspar, and spaise to abundant aegirine-augite(?) The hornblende granodior ite gioup is char acter ized by calcic oligoclase, and one or mole of hornblende, pyroxene, or biotite The hornblende gianodiorite group is limited geographically to the lower Fall River area, and the light-colored granodiorite group is found mostly in the eastein part of the area. The members within each of the light-colored
\end{abstract}


granodiorite, quaitz monzonite, and bostonite groups form an intrusive sequence of nearly the same age

The porphyries weie intıuded along preexisting planes of weakness in the Precambrian locks, particularly along joints, foliation surfaces, contacts, faults, and axial planes of folds The form of individual bodies changed progiessively with tıme fiom irregularly shaped steep-walled plutons to long, thin dikes Intı usion of the rocks was largely passive, the plugs formed dominantly by stoping, and the dikes entered fractures opened by tectonic movements during the Laramide orogeny Local explosive activity that resulted in the formation of breccias appears to have initiated some of the periods of magmatic activity

The locks of the igneous sequence are tentatively considered to have been delived from two separate magma chambers The hornblende granodiorite gloup, which constitutes a minor magma series, appeais to have stemmed fiom a relatively small magma chamber The light-colored granodiorite, quartz monzonite, and bostonite groups, which constitute a major magma series, on the other hand appear to have been derived from a much larger magma chambel Successively youngel members within each group are more felsic than the previously intruded one

The members of each group and each series of the rock sequence show a progressive enrichment in uranium and thorium from the more mafic to the more felsic phases A late phase of the quartz bostonite porphyry, the youngest member of the major magma series, was particularly enriched in the radioactive elements, and it probably was the source for the solutions that pioduced the uranium in the hydrothermal vein deposits at Central City and adjacent districts The biotite-quaitz latite porphyry may also have been a local minor source of uranium

\section{INTRODUCTION}

The area covered by this report occupies 48 square miles in the central part of the Front Range mineral belt (fig. 57), within Gilpin and Clear Creek Counties, Colo. It includes the mining districts of Central City, Idaho Springs, Freeland-Lamartine, Chıcago Creek, and Lawson-Dumont-Fall River.

Abundant small bodies of radioactive porphyritic rocks of early Tertiary age occur in Precambrian crystalline rocks, which constitute the core of the Front Range. For the most part the intrusive rocks are in well-foliated metasedimentary gnessses and schists, but to a lesser extent they are in the more massive igneous rocks. The porphyries range in composition from granodiorite to alkalic granite and were intruded in a time sequence as small irregular plutons and dikes.

The first intensive study of the Tertıary intrusive rocks in the area was made by Spurr, Garrey, and Ball (1908) in the Georgetown quadrangle, which includes the southwest part of the area of this report. Later, Bastin and Hull (1917) studied the Central City quadrangle, part of which is included in the northern part of the area. Data from these reports were used as the basis for further studies in the mineral belt by Lovering and Goddard (1938) who presented an excellent summary of some of the broader regional aspects of the 
PETROGRAPHY OF TERTIARY ROCKS, FRONT RANGE, COLO. 225

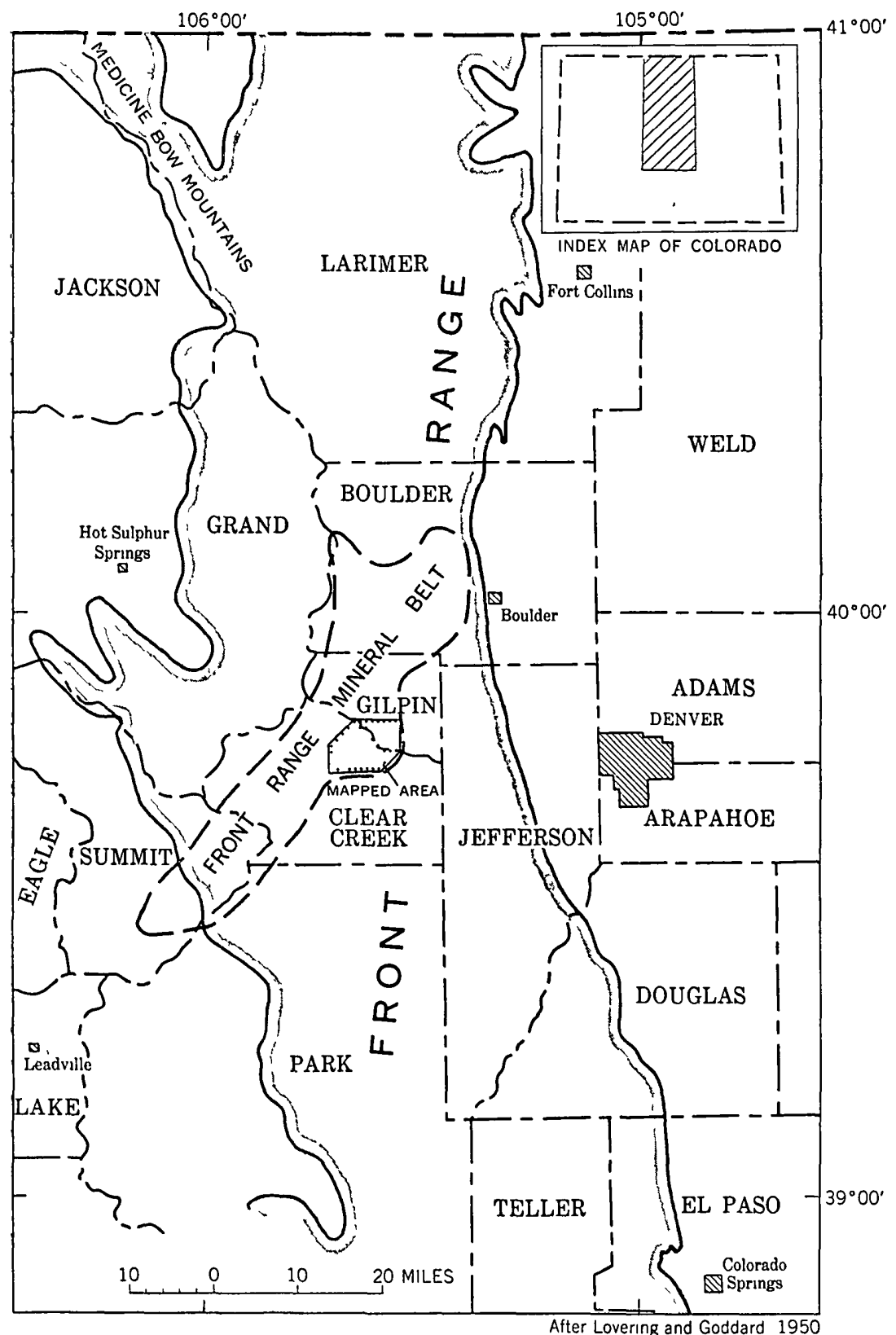

Frgurn 57 -Index map of the Front Range, Colo, showing location of the mapped area with reference to the mineral belt. 
intrusive rocks and related them to the Laramide deformation and to the accumulation of sediment in basins adjoining the Front Range highland. Later they summarized the data concerning these rocks throughout the Front Range (Lovering and Goddard, 1950). Beginning in 1949 and continuing for several years afterwards, George Phair, of the U.S. Geological Survey, studied the petrology and radioactivity of the Tertiary porphyries in the middle and northern part of the Front Range mineral belt. A preliminary report concerning the Central City district has been completed (Phair, 1952); a more comprehensive report is in preparation.

This report is based on investigations by the U.S. Geological Survey on behalf of the Division of Raw Materials of the U.S. Atomic Energy Commission. The investigations were started in 1952 and continued through the next two field seasons. The mining districts of Central City, Idaho Springs, Lawson-Dumont-Fall River, Freeland-Lamartine, and Chicago Creek were mapped in detail $(1: 6,000)$ as part of an investigation of the geology of the uranium deposits in the central part of the Front Range. A special study of the Tertiary igneous rocks was undertaken to classify the rocks and to determine the genetic relationships, if any, between the intrusive rocks and uranıum mineralization. Although the geologic mapping was done largely by the field members working in the respective districts, the author assisted in identlfication of the Tertiary rocks and developed the rock classification used in this report. Also, at places he studied critical areas of outcrop.

The map of the Tertiary igneous sequence (pl. 19) presented with this report was compiled by the author from the geologic maps of the Central City (P. K. Sims and others, written communication, 1956), Idaho Springs (R. H. Moench and A. A. Drake, written communication, 1955), Freeland-Lamartine (Harrison and Wells, 1956), Chicago Creek (Harrison and Wells, 1959), and LawsonDumont-Fall River districts (C. C. Hawley, and F. B. Moore, written communication, 1955). As the mapping was done in much greater detall than previously, much new information was accumulated regarding the distribution of the rock types and the structural relations of the rocks. Because the author believes that the rock units should be mappable units, the rocks are classified by features that can be observed megascopically and microscopically.

The laboratory investigation of the Tertiary igneous rocks consisted principally of petrographic studies. About 430 thin sections were studied. In addition, many analyses for chemical and equivalent uranium were made. George Phair, of the Geological Survey, kindly made available to the author thin sections and uranium determinations from rocks collected by him in the Central City dis- 
trict. Chemical studies of the rocks were beyond the scope of the present work.

The investigation has shown that the Tertiary porphyritic igneous rocks can be separated into mappable units that have consistent age relations; that during emplacement of the sequence there was a progressive change in mode of intrusion and form of the bodies from irregular plutons to well-defined dikes; that most bodies were intruded along preexisting structural weaknesses in the Precambrian crystalline rocks, principally along joints, faults, and foliation surfaces; that the rocks possibly were derived from two dufferent magmatic sources; and that the members of each of the two differentiation series show a progressive enrichment in thorium and uranium from the more mafic to the more felsic members.

\section{GEOLOGIC SETTING}

The Tertiary igneous rocks of the area are part of a narrow belt containing these rocks that extends from near Boulder to Breckenridge, Colo. The rocks vary widely in composition and form (Lovering and Goddard, 1938, p. 36). Other similar Tertiary porphyritic igneous rocks are present in the Mosquito and Sawatch Ranges, the Cameron Pass area northwest of Estes Park, and the Cripple Creek area west of Colorado Springs; basaltic flows, interbedded with the Denver formation, occur on the eastern flank of the Front Range of Colorado.

The Tertiary intrusive rocks in the Front Range mineral belt occur in Precambrian crystalline rocks. In the area of this report, as throughout the mineral belt (Lovering and Goddard, 1950, pl. 2), the intrusive rocks are found mostly in terranes containing wellfollated, folded gneiss and schist. They are much less common in the large bodies of relatively massive Precambrian igneous rocks, and where present, they are confined to the margins of these bodies. With the exception of biotite-quartz latite, the porphyries in the mapped area (pl. 19) were emplaced before the mineralization that yielded the ore deposits of the region. Generally the dikes and metalliferous veins occupy different fractures.

Thirteen types of porphyritic intrusive rocks, which can be combined into four groups whose members have simllarities in age, petrography, and geographic distribution, are described in this report. The four groups of porphyries and the types they include are hormblende granodiorite group, which includes hornblende granodiorite, biotite granodiorite, biotite-quartz monzonite, and biotitequartz latite porphyries; light-colored granodiorite group, which includes light-colored granodiorite, albite granodiorite, and alkalic 
syenite porphyries; quartz monzonite group, which includes quartz monzonite, granite, and alaskite porphyries; and bostonite group, which includes bostonite, trachytic granite, and quartz bostonite porphyries. Within each of the rock types, phases are recognized that differ somewhat from the normal phases. Intrusion breccias occur in or are spatially associated with light-colored granodiorite porphyry and quartz monzonite porphyry bodies in the eastern and northern parts of the area. They consist of variable quantities of wallrock fragments embedded in an igneous matrix.

\section{FORM OF INTRUSIVE ROCKS}

The Tertiary intrusive rocks occur as plutons with short radiating dikes, as plutons with long dikes extending in a preferred direction, as long continuous dikes, and as short dikes which have a common trend. The plutons are step-walled irregular oblong igneous bodies that range from maximum horizontal dimensions of a few hundred feet to a few thousand feet. The dikes range in length from a few hundred feet to several miles, and in width from a few inches to a few hundred feet; the average width is about 15 feet. Most of the dikes dip more than $60^{\circ}$ : generally they dip to the north, but some dip south.

The form of the intrusive bodies is closely related to the rock type. With few exceptions the older intrusive rocks occur as plutons, whereas the younger intrusive rocks form dikes. The members of the granodiorites groups tend to occur mostly as plutons, the members of the quartz monzonite group occur mostly as small plutons and dikes, and the members of the bostonite group mostly form long continuous dikes.

\section{AGE AND SEQUENCE OF INTRUSION}

The porphyritic igneous rocks in the eastern part of the Front Range have been shown by Lovering and Goddard (1950, p. 47) to be early Tertiary in age. They are slightly older than the metalliferous veins of the region (Sims, 1956) which have been shown by lead-uranıum ratios in pitchblende to be about 60 million years old (Holmes, 1946; Faul, 1954, p. 263).

The sequence of intrusion of the porphyritic rocks is determined mainly by crosscutting relations and faulting relations, but in part by structural, textural, and compositional variations. The rocks in order of their probable age are given in figure 58.

The hornblende granodiorite and biotite granodiorite porphyries are inferred to be the oldest Tertiary intrusive rocks in the region because they occur as small plutons with few associated dikes. This 


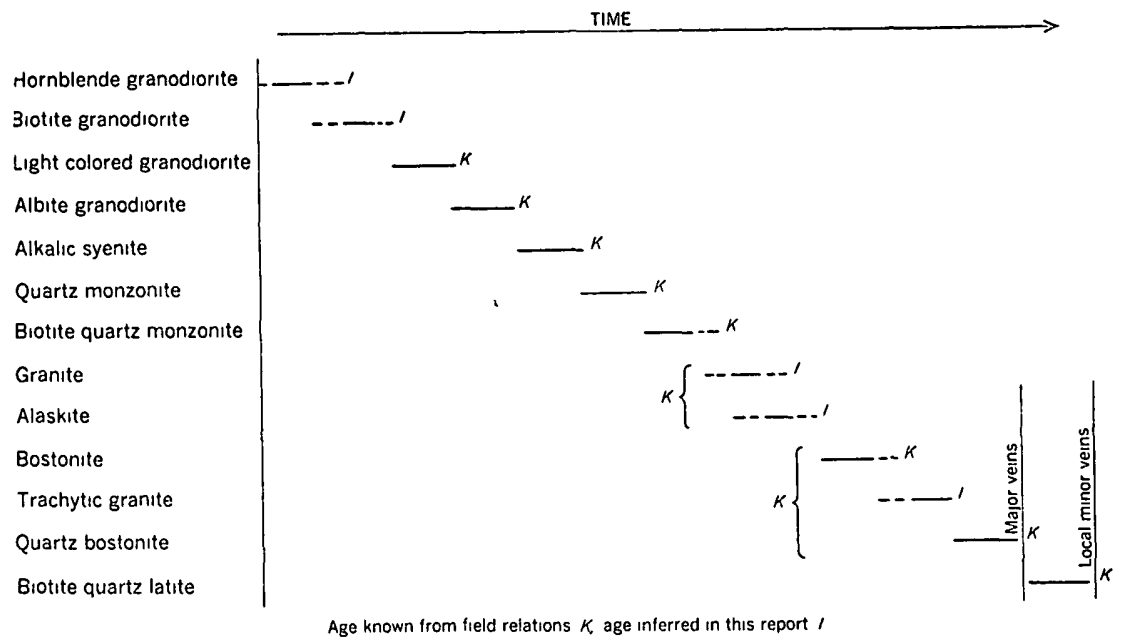

Figure 5S-Diagram showing the probable sequence of intrusion of the Tertiary igneous rocks

inference is based on the tendency of the earlier intrusive rocks to occur as plutons. The hornblende granodiorite porphyry is thought to be older than the biotite granodiorite porphyry because it has a more basic mineral suite. A body of light-colored granodiorite porphyry in the western part of the Gilson Gulch area is cut by an albite granodionte porphyry dike, and a pluton of albite granodiorite porphyry on the east side of the Elkhorn pluton is cut by a dike of alkalic syenite porphyry. Quartz monzonite porphyry cuts albite granodiorite porphyry in the western part of the Gilson Gulch area and cuts alkalic syenite porphyry on Banta Hill. The age relation between granite porphyry and alaskite porphyry is not definitely known; but they are thought to be essentially contemporaneous because of simlarities in form, mineralogy, texture, and radioactıvity. The alaskite porphyry is indicated by Lovering and Goddard (1950, p. 44-47) to be younger than the quartz monzonite porphyry and older than the members of the bostonite group. The granite porphyry is cut by biotite-quartz latite near Cottonwood Gulch on Chicago Creek. Quartz monzonite porphyry is cut by biotite-quartz monzonite porphyry on the ridge west of Dumont, and both monzonites are cut and offset by bostonite porphyry east of Dumont. The trachytic granite porphyry is inferred on field relations and petrographic character to be intermediate in age between the older bostonite porphyry and younger quartz bostonite porphyry. South of Dumont and in the lower Spring Gulch area of Chicago Creek, trachytic granite porphyry both cuts and is cut by quartz bostonite porphyry. This suggests that it is in part younger and in part older 
than the quartz bostonite porphyry. The quartz bostonite porphyry, where it was observed on Quartz Hill, cuts bostonite porphyry. A relatively nonporphyritic phase of quartz bostonite porphyry cuts and offsets a porphyritic phase of the rock west of Central City, but the reverse age relation is shown on the ridge between Chicago Creek and Spring Gulch.

The metallıferous veins throughout the area cut all the porphyritic rocks except biotite-quartz latite porphyry, which cuts major veins in the Stanley, Lincoln, and Donaldson mines west of Idaho Springs. Biotite-quartz latite porphyry cuts quartz bostonite porphyry between Cottonwood Gulch and Spring Gulch along Chicago Creek. Local minor sulfide veins cut biotite-quartz latite porphyry in the Stanley mine and Dorit mine on Chicago Creek. This indicates that some mineralization, probably unimportant economically, occurred after the emplacement of the igneous sequence. The intrusive breccias are essentially contemporaneous with the rocks with which they are associated; therefore, periods of intrusive brecciation occurred during light-colored granodiorite porphyry and quartz monzonite porphyry intrusion.

\section{TEXTURE AND INTERNAL STRUCTURES}

The Tertiary igneous rocks are characteristically porphyritıc; but a few dikes of bostonite porphyry, biotite-quartz latite porphyry, and alaskite porphyry are nearly equigranular and very fine grained. The phenocrysts in the Tertiary rocks are generally less than a quarter of an inch long, and they are embedded in a fine-grained groundmass. An exception is the hornblende granodiorite porphyry, which has phenocrysts as much as an inch long set in a mediumgramed groundmass The size and number of phenocrysts and the groundmass texture vary from dike to dike, but individual dikes are similar throughout. Within each group, the younger rocks are finer grained and contain fewer phenocrysts than the older rocks of the group.

Various internal structures, flow structures, joints, and chilled margins occur in the rocks. Flow structures, shown by the alinement of feldspar crystals, can be seen both megascopically and microscopically in the younger intrusive rocks and are particularly evident in the bostonite group and the biotite-quartz latite porphyry. Closespaced joints are present near the margins of some of the plutons. The dikes of the younger intrusive rocks, particularly the biotitequartz latite porphyry and the bostonite group, commonly have chilled borders that are as much as an inch thick; but chilled borders were not observed in the older rocks. The presence of chilled border 
phases along the younger dikes indicates that these dikes probably were intı uded into relatively cool country rocks.

\section{PETROGRAPHY}

The porphyritic igneous rocks of the region can be separated into mappable rock units on the basis of color, texture of the groundmass, size, shape, and abundance of the phenocrysts, qualitative mineralogy, approximate quantitative mineralogy, and character of fractured surfaces.

Although most of the 13 kinds of porphyries are distinct in their petrographic characteristics, each has variations from the normal or typical rock. These variations tend to cause gradations from one distinctive kind to another, as might be expected from a series of closely related intrusive bodies. The alteration partly or completely destroys the mafic minerals and feldspars, which are critical for the identification of members of the sequence As a consequence of the slight gradation between kinds of rock and the intense alteration of many of the rocks, identification of the atypical varieties may not always be correct. The age relations and estimated modes given in this report are those of the least altered typical rock and its varieties that can be distinguished with a reasonable degree of certainty.

Because of the fine-grained groundmass and the widespread alteration of the rocks, staining procedures were used to supplement thinsection analysis. Only in the coarsest of the rocks is an accurate modal analysis possible; in the others it is necessary to estimate the percentages of the mineral constituents. Staining procedures were used to assist in the identification of the extremely fine grained minerals and to distinguish the alkalic feldspars, especially when they were altered. With some modification the sodium cobaltinitrite stain for potassium (Gabriel and Cox, 1929) and the malachite green stain for feldspar (Russell, 1935) were used. Most of the staining was by the sodium cobaltinitrite method on rock slabs and thin sections, but commonly both methods were used together. The color of hand specimens was determined by comparison with the Rock color Chart of the National Research Council distributed by the Geological Society of America. In the section that follows, the very fine grained, low-birefringence minerals are referred to as clay minerals; fine-grained highly birefringent micaceous material is called sericite.

\section{CLASSIFICATION}

The classification of the Tertiary intrusive rocks used in this report is essentially the same as that used by Spurr, Garrey, and Ball (1908) in the Georgetown quadrangle and later adopted by Bastin 
and Hill (1917) in the Central City quadrangle and by Lovering and Goddard (1950) throughout the Front Range. Some of the modifications in terminology proposed by Phair (1952) are used by the author; in addition, new names are introduced by the author for previously unrecognized rock types. Although the classification is based on the kind and quantity of minerals found in the rocks, it is often necessary to distinguish rocks by qualitatıve mineralogy and texture rather than by quantitative mineralogy.

The rock types of the region can be combined into four groups, the light-colored granodiorite group, the quartz monzonite group, the bostonite group, and the hornblende granodiorite group and according to similarities into groundmass texture, mineral suite, and color. Some of these groups have similar ages and geographic distributions. The bostonite group has a distinctive trachytic or bostonitic texture, contains abundant alkalic minerals, and has a characteristic reddish-brown to lilac color; the other groups have a granular texture and are various shades of gray. The hornblende granodiorite group characteristically contains a greater abundance of more calcic plagioclase than the other groups and a suite of ferromagnesian minerals, hornblende, and pyroxene or biotite. Members of this group are concentrated in the lower Fall River area. The members of the light-colored granodıorite group contain abundant sodic minerals and sparse ferromagnesian minerals, they are nearly contemporaneous in age (fig 58), and are restricted mostly to the eastern part of the area. The members of the quartz monzonite group are nearly of equivalent age and contain an abundance of potassic minerals and quartz in the groundmass.

\section{DESCRIPTION OF ROCKS}

\section{LIGHT-COLORED GRANODIORITE GROUP}

The light-colored granodiorite porphyry, albite granodiorite porphyry, and alkalic syenite porphyry are placed in the light-colored granodiorite group because of similarity in texture of the granular groundmass, the gray color, sparsity of ferromagnesian minerals, and abundance of sodic minerals. The rocks also show, from the oldest to the youngest, a gradual increase in their content of sodic minerals.

The rock types in the group are not closely similar in megascopic appearance. The distinguishing feature of the light-colored granodiorite porphyry that is seen in hand specimen is a general "dotted" appearance, produced by small, rounded, uniform-sized phenocrysts that are embedded in aphanitic gray groundmass. The rock is rather simllar in appearance to the quartz monzonite por- 
phyry, but the small phenocrysts in the latter are variable in size and form euhedral laths. Albite granodiorite porphyry is distinguished by inconspicuous pinkish-gray phenocrysts, about one-fourth of an inch long, in a pinkish-gray groundmass flecked with small grains of ferromagnesian minerals. Large gray conspicuous commonly diamond-shaped phenocrysts that are bent and show wavy reflections are characteristic of the alkalic syenite porphyry.

The microscopic features that distinguish the light-colored granodiorite porphyry from the hornblende granodiorite, biotite granodiorite, and quartz monzonite porphyries are an abundance of oligoclase and a general absence of ferromagnesian minerals. An abundance of antiperthitic albite is a characteristic feature of the albite granodiorite porphyry. Abundant albite and very minor quartz distinguish the alkalic syenite from other similarly appearing rocks. The petrographic characteristics of this group are summarized in table 1.

\section{IIGHT-COLORED GRANODIORITE PORPHYRY}

The light-colored granodiorite por phyry occurs as plutons as much as 3,000 feet across with associated dikes in the east-central part of the area and as dikes in the southeast and south-central part (pl. 19). The Gregory Hill pluton, about half a mile southeast of Central City, has several radiating dikes; the southern part of the pluton contains some brecciated wallrock. An irregular crescent-shaped body crops out southwest of the Gregory Hill pluton near the intersection of Russell and Leavenworth Gulches; a dike extends eastward from the pluton. Several small bodies and dikes of the rock are present on the south side of Russell Gulch. Farther south on Banta Hill, another pluton, which has several radiatıng dıkes, is cut by branching bostonite dikes. The northeast projection of the pluton is free from wallrock contamination, but the remainder contains two large mappable blocks and many breccia fragments of the country rock. Short dikes trending east and northwest occur west of the Banta Hill pluton. Thin branching dikes of light-colored granodiorite porphyry are present about three-fourths of a mile south of the Banta Hill pluton in the headwaters area of Gilson Gulch. A nearly eastward trending dike that is cut by a quartz monzonite porphyry dike is on the east slope of the headwaters of Gilson Gulch. Short, nearly eastward trending dikes occur about 1.5 miles northwest of Idaho Springs near the junction of Trall Creek and Clear Creek and about 2 miles southwest of Idaho Springs near the head of Cottonwood Gulch. 
TABLE 1.-Petrographic characterıstıcs of the Tertiary igneous rocks

$[X$ indicates mineral is present but variety not determined]

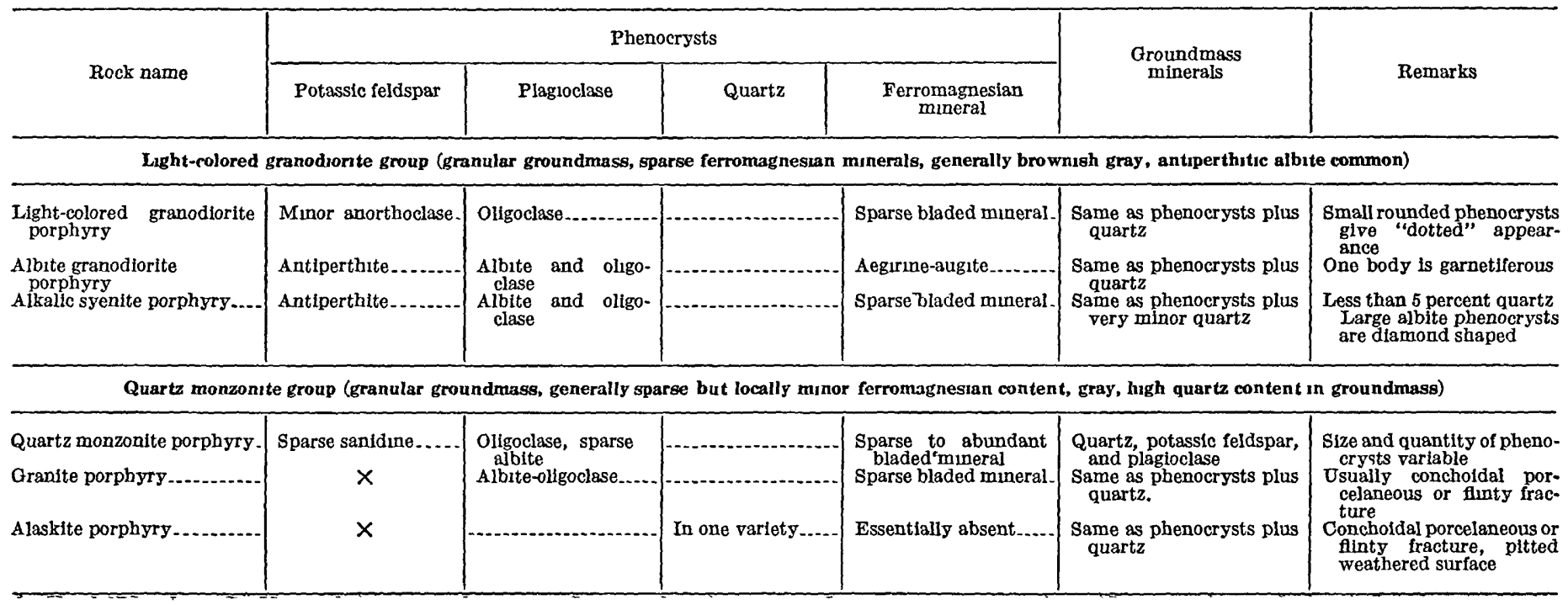


Bostonite group (bostonitic groundmass, sparse ferromagnesian minerals, general reddısh brown to lılac)

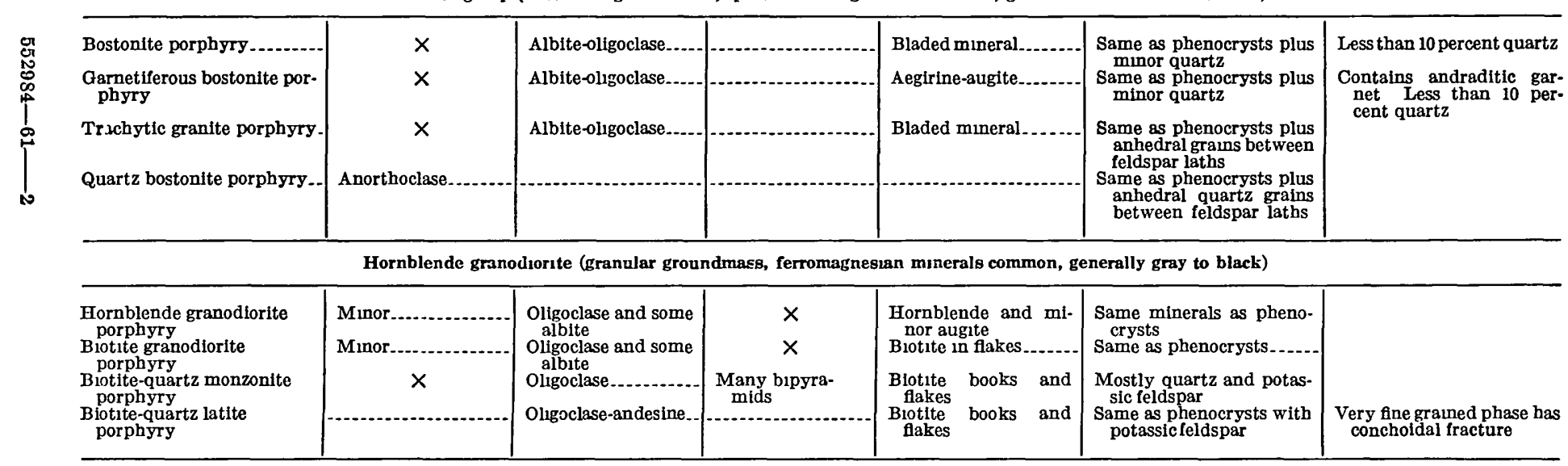


The light-colored granodiorite porphyry contains very light-gray feldspar phenocrysts in a light-gray aphanitic groundmass. In the observed hand specimen, the phenocrysts are of two different sizesthe larger euhedral crystals are about half an inch long and the smaller ones range from one-sixteenth to one-eighth of an inch in length. The smaller phenocrysts are generally equidımensional, appear rounded, and are uniformly scattered through the rock giving it a characteristic "dotted" appearance. In the dikes large phenocrysts are rare, and the smaller sized phenocrysts, being about onesixteenth of an inch in diameter are barely visible. Brown pseudomorphs of an unknown mineral replace sparse ferromagnesıan minerals. Weathered surfaces are essentially the same color as the freshly broken rock. The wallrock fragments, which are locally abundant in parts of the plutons, vary widely in size and angularity; some inclusions are mappable, whereas others can be seen only with the ald of the microscope. Some of the fragments are sharply angular while others are well rounded. The fragments are only slightly altered. In the highly contaminated parts of the plutons, the color of the rock remains light gray, but the contaminated branching dike near the head of Gilson Gulch is brownish gray. The most highly contaminated parts of the light-gray, light-colored granodiorite porphyry resembles typical albite granodiorite porphyry.

The texture of the groundmass of the light-colored granodiorite porphyry is hypidıomorphic granular to polkılıtic granular. Poıkilitic granular texture is used in this report to describe a texture in which urregular to circular mutually sutured quartz grains contain minute laths and irregular grains of feldspar. Quartz occurs as irregularly shaped clear anhedral grains and as equidımensional grains with minute, generally less than $002 \mathrm{~mm}$ in diameter, inclusions of anhedral grains and euhedral laths of potassic feldspar and plagioclase. Potassic feldspar and plagioclase also occur as larger grains, as much as $0.2 \mathrm{~mm}$ in diameter, between the quartz grains. The large phenocrysts observable in hand specimens are euhedral to subhedral anorthoclase crystals that are generally unaltered in contrast to the highly altered small phenocrysts and groundmass. The name "anorthoclase" is applied to the feldspar that is biaxial (-) with a moderate $2 \mathrm{~V}$ and an index less than balsam; fine twinning lamellae are observed in some specimens and staining shows the presence of potassium. The oligoclase, which is highly altered to clay, occurs as euhedral to subhedral, mostly equidimensional crystals ranging from 0.1 to $4 \mathrm{~mm}$ across. The crystals are zoned ond show pericline-albite twinning. In some rocks and twinned oligoclase crystals have borders of untwinned albite. Small phenocrysts of untwinned albite also occur in some samples. A bladed ferromag- 
nesian mineral is completely replaced by sericite and magnetite. Accessory minerals of the rock are magnetite-llmenite, sphene, apatite, and zircon.

Thin sections of the rock from contaminated parts of the plutons show that the phenocrysts have been broken and that the textural features characteristic of the uncontaminated rock are partly obscured by the addition of foreign material. In the contaminated, branching dikes at the head of Gilson Gulch the overall texture of the rock is similar to the normal texture, but certain features of the rock are notably different. The groundmass has an allotriomorphicgranular instead of a hypidiomorphic-granular texture and consists of anhedral grains of quartz, orthoclase, and plagioclase that range in size from 0.05 to $0.2 \mathrm{~mm}$. The untwinned albite grains and albite margins of oligoclase grains differ from the mineral in the normal rock in containing antiperthite.

The light-colored granodiorite porphyry is variable in composition mostly because the groundmass of the finer grained dike rocks contains unusually large quantities of potassic feldspar. The approxlmate quantities of minerals present are quartz, 20 to 35 percent; anorthoclase, 0 to 5 percent; potassic feldspar, 15 to 25 percent; oligoclase, 40 to 60 percent; albite, 0 to 10 percent; and a ferromagnesian mineral, 1 to 5 percent; accessory minerals occur in trace quantities.

\section{ALBITE GRANODIORITE PORPHYRY}

Albite granodiorite porphyry is exposed only in the east-central part of the mapped area (pl. 19) between the headwaters area of Gilson Gulch and Pleasant Valley. Three major plutons are exposed in this area; they are the Elkhorn pluton to the northeast, the Sun and Moon pluton immediately west of the southern part of the Elkhorn pluton, and the Gilson pluton to the southeast. A small body crops out southwest of the Sun and Moon pluton. One major northeastward-trending dike, as well as several small dikes, is exposed; some dikes extend outward from the plutons, whereas others are isolated. The Elkhorn pluton is a compound igneous intrusive body for it contains intrusive rocks other than albite granodiorite porphyry.

The albite granodiorite porphyry is a pinkish-gray seriate porphyritic rock with generally inconspicuous phenocrysts. The feldspar phenocrysts, constituting about 40 percent of the rock, are in a groundmass that is flecked with dark, mafic minerals In most specimens they are about one-fourth of an inch long, but in some they are as much as half an inch long. The granodiorite that constitutes the Sun and Moon pluton is unusual because it is brownish gray rather than pinkısh gray and contains crystals of garnet that appear black 
in hand specimen. In typical weathered specimens the phenocrysts are conspicuous in the brown groundmass that is colored by limonitic alteration of the ferromagnesian minerals.

The rock has a hypidiomorphic granular texture. Three feldspars are present; they are oligoclase, albite, and potassic feldspar. The oligoclase occurs as euhedral to subhedral laths, ranging in length from 0.1 to $6.5 \mathrm{~mm}$, that are zoned and show albite twinning. The composition of these crystals range from intermediate oligoclase in the center to albite at the margins. The larger crystals contain inclusions of small plagioclase crystals. The albite is untwinned, some occurs as margins of varying width on oligoclase crystals, and the remainder occurs as individual zoned crystals ranging in size from 0.1 to $3 \mathrm{~mm}$. Although most of the albite forms subhedral to anhedral grains, some of it forms euhedral equidimensional crystals. The albite contains most of the potassic feldspar in the rock in antiperthitic intergrowths. The potassic feldspar forms stringers and patches intergrown with albite and rarely with oligoclase; locally it occurs as small subhedral to anhedral grains in the groundmass. Anhedral quartz grains, ranging in length from 0.02 to 0.2 $\mathrm{mm}$, occur in the groundmass and in crosscutting veinlets. Aegirineaugite occurs as subhedral to anhedral laths and grains that range in length from 0.1 to $1 \mathrm{~mm}$. Some of the crystals of aegirine-augite show color zoning with green on the margins and light green in the center. Some specimens of the rock have scattered biotite flakes. The garnet in the Sun and Moon pluton, which is brown and simlar to the andradite garnet identified in the garnetiferous bostonite, forms rounded, subhedral to anhedral grains that range from 03 to $1.5 \mathrm{~mm}$ in diameter. Accessory minerals in the albite granodorite porphyry are sphene, magnetite-ilmenite, apatite, allanite, and zircon.

The typical albite granodiorite porphyry is remarkably uniforr' in composition. The approximate range in mineral composition is quartz, 5 to 20 percent; albite, 35 to 40 percent; potassic feldspar, 10 to 20 percent; oligoclase, 30 to 35 percent; and aegirine-augite, 3 to 5 percent; the accessory minerals constitute less than 1 percent of the rock. A sample from the Sun and Moon pluton is unusual because it contains approximately 48 percent albite, 18 percent potassic feldspar, 9 percent oligoclase, 20 percent aegirine-augite, and 2 percent garnet.

\section{ALKAIIC SYENITE PORPHYRY}

Alkalic syenite porphyry is exposed in the east-central part of the area. It forms a small pluton on Banta Hill, adjacent to the north end of the Elkhorn albite granodiorite porphyry plutons, a small body about 1,500 feet east of the junction of Russell and Leaven- 
worth Gulches, and small dikes about 1,000 feet southeast of the plug on Banta Hill (pl. 19).

The alkalic syenite porphyry is a light-brownish-gray rock with conspicuous dark-gray phenocrysts. The phenocrysts are entirely feldspar, and they constitute from 25 to 50 percent of the rock. They range in length from one-eighth to one-half inch, are commonly diamond shaped, are usually bent and give a wavy reflection from cleavage surfaces, and locally have rims or centers that are altered white. Weathered surfaces are light gray, and exposed areas of the rock appear polished.

The groundmass of the alkalic syenite porphyry is hypıdıomorphic granular and variable in grain size and mineralogy. In the Banta Hill body the groundmass grains range from 0.1 to $0.5 \mathrm{~mm}$ in diameter, whereas in the Russell Gulch body they range from 0.02 to $0.1 \mathrm{~mm}$. The feldspars in the two bodies vary in composition and size. The porphyry of Banta Hill contains albite and oligoclase, whereas the rock near Russell Gulch contains sodic olıgoclase. The albite occurs in euhedral to subhedral crystals that range in length from 0.2 to $10 \mathrm{~mm}$ and show zoning but no twinning. Oligoclase from the Banta Hill rocks occurs as euhedral to subhedral laths, 0.2 to $1 \mathrm{~mm}$ in length, that show pericline-albite twinning. The oligoclase in the Russell Gulch body occurs in euhedral to subhedral crystals that range in size from 0.2 to $1.3 \mathrm{~mm}$. Generally the crystals are zoned and untwinned, but in a few crystals carlsbad twinning is present, and some of the smaller grains show fine albite twinning. All the plagioclase feldspars contain antiperthitic intergrowths of potassic feldspar, principally as patches and stringers. A euhedral to subhedral ferromagnesian mineral, which forms laths 0.2 to 10 $\mathrm{mm}$ long, is replaced by clay, limonite, magnetite, and quartz. Accessory minerals of the rock are apatite, magnetite, ilmenite, and sphene.

Although the mineralogy of the various bodies of alkalic syenite porphyry differ in detall, it is grossly similar, as can be seen by comparison of modal analyses from the Banta Hill and Russell Gulch bodies. The Banta Hill body contains approxımately 3 percent quartz, 44 percent albite, 15 percent oligoclase, 32 percent potassic feldspar, 4 percent a ferromagnesian mineral, and trace amounts of the accessory minerals. The Russell Gulch body contains about 2 percent quartz, 68 percent oligoclase, 26 percent potassic feldspar, 4 percent a ferromagnesian mineral, and trace amounts of the accessory minerals. The total plagioclase and the ratios of sodium to calcium of the plagioclase in the two samples are about the same, for the mixture of the oligoclase and albite of the Banta Hill sample is essentially equivalent to the sodic oligoclase of the Russell Gulch sample. 


\section{QUARTZ MONZONITE GROUP}

The members of the quartz monzonite group-quartz monzonite porphyry, granite porphyry, and alaskite porphyry-are grouped together because the feldspars are mostly oligoclase and orthoclase, the quartz content is generally high, the ferromagnesian mineral content is low in most of the specimens, and the appearance of the groundmass is similar. (See table 1 for a summary of the petrographic characteristics of the group) The groundmass of the granite, alaskite, and part of the quartz monzonite porphyries has a characteristic conchoidal, flinty to porcelaneous fracture.

The quartz monzonite porphyry is characterized by medium to large feldspar phenocrysts, from one-elghth to one-half 1 nch in diameter, which are generally euhedral laths that vary widely within individual specimens. Some of the rock has a reddish-brown groundmass and is difficult to distinguish from bostonite porphyry, except under a microscope, where the granular groundmass can be seen. The granite and alaskite porphyries are nearly identical in megascopic appearance, but they can be separated microscopically, for the feldspar of the granite is partly plagloclase. Both rocks fracture similarly and contain sparse phenocrysts.

\section{QUARTZ MONZONITE PORPHYRY}

The quartz monzonite porphyry is the most abundant, widespread, and variable rock in the area. It occurs throughout the area as dikes of diverse trends and rarely as small plutons and is particularly abundant in the eastern part of the region (pl. 19). Although the rock on the average has the composition of quartz monzonite, it ranges in composition from granodiorite to granite. Two dominant phases are recognized: a phase that contains small phenocrysts and sparse quantities of ferromagnesian minerals and a phase that contains relatively large phenocrysts and several percent of ferromagnesian minerals. Other minor phases that differ slightly in composition, texture, or both are present locally but are not quantitatively important.

Dikes of quartz monzonite porphyry, which trend in several directions, are present throughout the area (pl. 19). The dikes in the Lawson-Dumont area vary in length and generally trend eastward; those in the northwest part of the area trend northeastward. A remarkably long zone of dikes, which follow a northwestward-trending fault zone, extends from Fall River southeastward to the south slope of Bellevue Mountain, at which point the dikes curve northeast. A large proportion of the dikes occur in a belt about a mile wide that extends from the vicinity of Alps Mountain, west of Idaho Springs, to Black Hawk, a distance of about 8 miles; individual 
dikes trend northeast, essentially parallel to the trend of the belt; but in detall they vary in trend from north to east, commonly striking either north-northeast or east-northeast.

Two small plutons of quartz monzonite porphyry occur in the area - a crescent-shaped body on the south slope of Bellevue Mountain and a body in upper Chase Gulch. The latter consists of two separate plugs that stand out as topographic knobs above a flat surface eroded on a breccia that is interpreted by Sims, Drake, and Tooker (written communication, 1957) to be intrusive breccia. The breccia consists of subrounded fragments of wallrock, generally ony a few inches in maximum diameter, embedded in a matrix of igneous material.

Although the rocks included in quartz monzonite porphyry differ widely in composition, texture, or both, most can be grouped in trro distinctive phases, each characteristic of a specific geographic area. The quartz monzonite porphyry in the long belt extending along the eastern part of the area is characterized by small phenocrysts (less than one-fourth of an inch long) and sparse ferromagnesian minerals. The rock in the area north of Clear Creek and west of Fall River and in part of the southeast corner of the area is characterized by large phenocrysts (one-fourth to one-half inch long) and several percent of ferromagnesian minerals.

The quartz monzonite porphyry typically contains very light gray feldspar phenocrysts in a light-gray aphanitic groundmass. The northeastward-trending quartz monzonite porphyry dike that crosses the north slope of Maryland Mountain has an unusual pale-red groundmass and because of the color resembles the bostonites, which are so abundant in this area. Certain dikes, like those near the mouth of Chicago Creek and in the Gilson Gulch area, contain inconspicuous phenocrysts. Some of the more mafic dikes are altered to chlorite, epidote, and calcite, as well as the more common clay minerals and serıcite; and these rocks have a dark gray groundmass and green phenocrysts.

The phase of quartz monzonite porphyry that contains large phenocrysts is characterized by thin, tabular crystals one-fourth to one-half inch long that constitute from about 25 to 50 percent of the rock. These rocks generally contain from 5 to 20 percent ferromagnesian mineral which occurs as thin blades generally less than one-eighth of an inch long but at places as much as three-eighths of an inch long. The phase that is characterized by small phenocrysts is seriate porphyritic with equidimensional crystals, generally less than one-fourth of an inch long, that constitute as much as 50 percent of the rock and a ferromagnesian mineral that constitutes generally less than 5 percent. Nonporphyritic dikes of the rock occur 
near the mouth of Trail Creek and on the east slope of Bellevue Mountain.

The groundmass of the quartz monzonite porphyry as seen under the microscope is allotriomorphic granular and consists essentially of quartz, potassic feldspar, and plagioclase. The texture varies from an intımate mixture of these minerals in anhedral grains less than $0.1 \mathrm{~mm}$ in size to poikilitic granular in which the quartz grains are from 0.1 to $0.4 \mathrm{~mm}$ in length and the feldspar inclusions generally less than $0.05 \mathrm{~mm}$. In a group of dikes along the upper part of Mill Creek, the feldspar laths in the groundmass are usually large, and they are intergrown in a subparallel arrangement to produce a trachytic texture.

The feldspar phenocrysts in the coarse phenocrystic phase are oligoclase, which ranges in composition from sodic oligoclase in the smaller grains to calcic oligoclase in the larger grains; albite is also present in a few specimens. The oligoclase crystals are euhedral to subhedral plates that range from 0.5 to 10 millimeters in length, are zoned, and have carlsbad-pericline-albite twinning. The larger crystals generally show better twinning than the smaller. The albite crystals are zoned, untwinned, and about the same size as the oligoclase grains. Pseudomorphs of chlorite, epidote, and magnetite replace laths of a ferromagnesian mineral that ranges in length from 02 to $2 \mathrm{~mm}$. Epidote and clay have replaced much of the feldspar in some of the specimens, and calcite is present as a secondary mineral in the groundmass of some of the samples.

The phenocrysts in the phase characterized by small crystals consist of four kinds of feldspar: oligoclase, orthoclase, albite, and sanıdıne. The name "sanıdıne" is applied to the feldspar that is biaxial with a small $2 \mathrm{~V}$ and an index much lower than balsam; crystals are generally clear in contrast to the clouded orthoclase.

Euhedral to subhedral laths and aggregates of laths of plagioclase 05 to $5 \mathrm{~mm}$ long and ranging in composition from sodıc oligoclase to calcic albite are always present in this group of rocks. Twinning according to the albite and combined albite-carlsbad laws is commonly present, but pericline twinning is rare. Some of the crystals have centers of untwinned oligoclase. The orthoclase forms equidimensional, euhedral to subhedral crystals that range in length from 05 to $2 \mathrm{~mm}$ and are smaller than the oligoclase. Untwinned albite in crystals similar in size and shape to the orthoclase as present in some of the samples. Sanidine is rarely present in this rock. A ferromagnesian mineral is generally present in small quantities. Prımary accessory minerals are sphene, apatite, topaz, magnetiteilmenite, and zircon. 
Some specimens of both phases of the rock contain quartz grains and aggregates of grains in veinlets. Most of this quartz is probably the result of wallrock contamination or secondary filling of openings. Other samples show obvious inclusions of wallrock.

The quartz monzonite porphyry ranges in composition from granite to granodiorite. The phase characterized by small phenocrysts contains approximately 40 to 50 percent quartz, 25 to 30 percent orthoclase, 20 to 30 percent plagioclase, and less than 5 percent a ferromagnesian mineral. The dike with the pale-red groundmass contains approximately 18 percent quartz, 52 percent orthoclase, 27 percent plagioclase, and 2 percent ferromagnesian mineral. The large-phenocryst phase contains approximately 25 percent quartz, 20 to 30 percent orthoclase, 0 to 10 percent albite, 20 to 40 percent plagioclase, and 5 to 20 percent ferromagnesian mineral.

\section{GRANITE PORPHYRY}

The granite porphyry is exposed as short, narrow, generally northeastward-trending dikes at road level along Chicago Creek, on the slope north of Chicago Creek in the vicinity of Cottonwood Gulch, west of Virginia Canyon and half a mile north of Idaho Springs, and in the vicinity of Banta Hill (pl. 19).

Two types of granite porphyry are present in the area. The more abundant type has a gray to pinkish-gray aphanitic groundmass and sparse pinkish-gray feldspar phenocrysts. The groundmass usually has a characteristic conchoidal porcelaneous or flinty fracture, but an irregular granular-appearing fracture also occurs. The phenocrysts are generally less than one-fourth of an inch long and constitute less than 5 percent of the rock. Some specimens have small reddish-brown pseudomorphs, which probably formed after ferromagnesian mineral phenocrysts. Weathered surfaces are tan and characteristically pitted by the removal of the phenocrysts. Although granite porphyry closely resembles alaskite porphyry in hand specimen, the granite porphyry contains fewer feldspar phenocrysts, is devoid of quartz phenocrysts, and contains ferromagnesian minerals.

The less abundant type of granite porphyry is a fine-grained lightbrownish-gray rock that has the appearance of aplite. Phenocrysts are few and inconspicuous. This type of granite porphyry is exposed as a dike on the south side of the group of granite porphyry dikes north of Idaho Springs.

The groundmass texture of the more abundant type is hypidiomorphic granular, and the rock consists essentially of irregular grains of quartz and subhedral to anhedral grains of alkalic feldspar. The phenocrysts are albite-oligoclase, orthoclase, and in some speci- 
mens, a ferromagnesian mineral. The albite-oligoclase is euhedral albite-pericline-twinned laths that range from 0.4 to $5 \mathrm{~mm}$ in length. Orthoclase phenocrysts are subhedral to anhedral laths and plates that range from 0.5 to $3 \mathrm{~mm}$ in length. The orthoclase and plagioclase commonly have sutured mutual boundaries. Aggregates of clay, magnetite, and limonite fill euhedral forms 0.1 to $1 \mathrm{~mm}$ long that were probably ferromagnesian minerals. Accessory minerals are sphene and magnetite-ilmenite.

The less abundant fine-gramed granite porphyry has a hypidiomorphic-granular texture and consists of albite-oligoclase, orthoclase, quartz, and biotite. The albite-oligoclase occurs in subhedral to anhedral, partly twinned to untwinned, antiperthitic crystals that range in length from 02 to $15 \mathrm{~mm}$. The twinning present in the plagioclase is albite or carlsbad. The orthoclase is in subhedral to anhedral grains that range from 01 to $1 \mathrm{~mm}$ in length. Quartz occurs as scattered, bent anhedral grains and aggregates that range from 0.04 to $02 \mathrm{~mm}$ in length; most of the crystals in the rock show pronounced cleavage or parting. Accessory minerals are zircon and magnetite-1lmenite.

Aslde from quartz, which is present in greater quantity in the aplitic type, the minerals in the two types of granite porphyry occur in about the same proportions. The approximate average composition of the granite porphyry is 20 percent quartz, 45 percent potassic feldspar, 34 percent plagioclase, and 1 percent a ferromagnesian mineral. A modal analysis of a sample from the aplitic dike shows quartz, 43 percent; orthoclase, 34 percent; plagioclase, 22 percent; and biotite, 1 percent. Trace amounts of the accessory minerals are present.

\section{ALASKITE PORPHYRY}

Alaskite porphyry is exposed only in the vicinity of Alps Mountain west of Idaho Springs (pl. 19). A small pluton with radiating dikes crops out about half a mile north of Alps Mountain; and a short, nearly east-strikıng dike is present about 1 mile to the northwest. A long, east-northeast-striking dike that has several branches is exposed about half a mle south of Alps Mountain.

Two varieties of alaskite porphyry are recognized. One contains numerous feldspar phenocrysts, and the other contains quartz phenocrysts and sparse feldspar phenocrysts. The variety with the abundant phenocrysts is restricted to the area north of Alps Mountain. It has a light-gray, yellowish-gray to pinkish-gray groundmass and very light-gray equidimensional phenocrysts, generally less than one-fourth of an inch long, which constitute from 15 to 20 percent of the rock. The rock has a characteristic porcelaneous to flinty conchoidal fracture. Weathered surfaces are very light gray and 
are generally pitted by the removal of the feldspar phenocrysts. The alaskite porphyry south of Alps Mountain is simllar in general appearance to that to the north. The groundmass is similar in composition and texture, and the feldspar phenocrysts have similar sizes and shapes, but they are generally pink and fewer in number, constituting from 5 to 10 percent of the rock. Clear quartz phenocrysts generally less than one-eighth of an inch long constitute a few percent of this rock.

The groundmass is generally allotriomorphic granular, but most of the specimens from the bodies on the north side of Alps Mountain are poikilitic granular. The groundmass consists of quartz and potassic feldspar in anhedral grains, 0.02 to $0.3 \mathrm{~mm}$ in diameter in about equal proportions. The feldspar is orthoclase, which occurs in euhedral equidimensional crystals 05 to $3 \mathrm{~mm}$ long, some of which show carlsbad twinning. The quartz phenocrysts are anhedral and 05 to $2 \mathrm{~mm}$ in diameter. Deep embayments in the quartz caused by corrosion are filled by the groundmass constituents. Small quantities of euhedral to subhedral ferromagnesian mineral laths, 0.2 to $1 \mathrm{~mm}$ long, which have been replaced by quartz and magnetite, are present in some of the specimens. Accessory minerals are sphene, apatite, topaz, magnetite-1lmenite, and zircon.

The composition of both varieties of the rock appears to be similar. The alaskite porphyry contains approximately 40 to 45 percent quartz, 50 to 60 percent potassic feldspar, as much as 2 percent ferromagnesian mineral in a few specimens, and trace amounts of accessory minerals.

\section{BOSTONITE GROUP}

The bostonite group, consisting of bostonite porphyry with a garnetıferous variety, trachytic granite porphyry, and quartz bostonite porphyry, can be distinguished from all other Tertiary intrusive rocks in the area by its trachytic or bostonitic groundmass texture, which is observable under the microscope.

The members of this group cannot easily be recognized in hand specimen, but certain diagnostic megascopic features are readıly apparent The dominant variety of trachytic granite porphyry is characterized by distinctive large white subrounded phenocrysts; the garnetıferous bostonite porphyry can be distinguished by visible garnets; and the nearly nonporphyritic phase of quartz bostonite porphyry is characterized by its uniformly dark red color. The quartz bostonite porphyry is distinguished microscopically from the other two members of the group by its lack of ferromagnesian minerals and plagioclase. Bostonite is distınguished from trachytic granite by containing generally less than 5 percent quartz. (See 
table 1 for a summary of the petrographic characteristics of the group.)

BOSTONITE AND GARNETIFEROUS BOSTONITE PORPHYRY

Bostonite and garnetıferous bostonite porphyry are distributed over most of the eastern part of the mapped area (pl. 19). Bostonite porphyry is evenly distributed in the area between Central City and Idaho Springs, and dikes of the rock extend southwestward to the south slope of Alps Mountain. Other dikes occur west and south of Dumont. Garnetıferous bostonite porphyry is present from west of Alps Mountain northeastward and northward to Spring Gulch, east of Dumont. Both varieties of bostonites generally occur as long, narrow branching dukes, although small plutons and short lenticular dikes are common. South of Central City the dominant trend of the dikes is east and northeast; from north of Idaho Springs to Alps Mountain, the trend is dominantly northeast. Northwest of Alps Mountain and near Dumont, the dikes trend east, northeast, and north. Northwestward-trending dikes are rare in the area Most of the dikes dip steeply, but those south and west of Alps Mountam dip at angles as low as $33^{\circ}$.

The two varieties of bostonite porphyry, although similar in essential characteristics, differ significantly in mineralogy, color, and grain size.

\section{BOSTONITE PORPHYRY}

The bostonite porphyry is a seriate porphyritic rock that has a pink aphanitic groundmass, white feldspar phenocrysts, and generally small phenocrysts of a bladed ferromagnesian mineral. In typical specimens the feldspar phenocrysts constitute 15 to 30 percent of the rock, but in some dikes in the vicinity of Alps Mountain they make up less than 5 percent of the rock. The phenocrysts are generally individual laths or aggregates less than one-fourth of an inch long, which are commonly aluned and give flow structure to the rock. The feldspar phenocrysts in some of the dikes along Chicago Creek occur as X-shaped aggregates, as much as half an inch long, that have been altered to a gray-green clay bordered by white clay. The gray-green clay has been identified (Harrison and Wells, 1959) as illite and the white clay as sericite. Most of the ferromagnesian mineral blades have been altered to brown pseudomorphs of an unknown mineral; these are generally less than onefourth of an inch long and make up less than 5 percent of the rock. Parallel alinement of the ferromagnesian mineral is common. Weathered surfaces of the rock are tan and pitted by the selective removal of the ferromagnesian mineral.

The texture of the groundmass, as seen under the microscope, is bostonitic-the feldspar laths are interlocking and have an imper- 
fect parallel orientation. The groundmass consists of subhedral to anhedral albite laths, anhedral grains of potassic feldspar, and anhedral grains of quartz. The grains of the groundmass generally range in size from 0.02 to $0.01 \mathrm{~mm}$ but in some specimens they may be as much as $0.3 \mathrm{~mm}$ long. The quartz and most of the potash feldspar in the rock are restricted to the groundmass. The phenocrysts are plagioclase, orthoclase, and a ferromagnesian mineral. The plaglioclase phenocrysts occur as euhedral to subhedral laths and aggregates of laths that range from 0.5 to $3 \mathrm{~mm}$ in length and which are compositionally zoned. They contain oligoclase in the center and calcic albite on the margins; typically the plagioclase shows combined pericline-albite twinning. The orthoclase phenocrysts are similar in size but more nearly equidimensional than the plagioclase, and generally they are untwinned. The ferromagnesian phenocrysts, which form single blades and aggregates, ranging from 04 to $2 \mathrm{~mm}$ in length, are entirely altered and replaced by quartz, magnetite, and serpentine in most specimens. The ferromagnesian mineral is probably aegirine-augite, for this mineral has been identified from a nearly unaltered specimen of garnetiferous bostonite porphyry. The accessory minerals are sphene, apatite, and zircon

The mineralogic composition of the bostonite is variable; the approximate estimated range in mineral composition is 1 to 10 percent quartz, 50 to 70 percent potassic feldspar, 20 to 45 percent plagioclase, 1 to 10 percent aegirine-augite, and a trace of accessory minerals. Although bostonite porphyry, as defined by Phair (1952, p. 10), should not contain more than 5 percent quartz by volume, a few specimens contain excess quartz in veinlets in small vugs. Other specimens, some of which contain wallrock inclusions, also contann excess quartz in the groundmass. Although it is not definitely known, it is probable that the excess quartz is of secondary origin or is related to contamination from quartz-bearing inclusions of wallrock.

\section{GARNETIFEROUS BOSTONITE PORPHYRY}

The garnetiferous bostonite porphyry is a seriate porphyritic rock that has a reddish-brown aphanitic groundmass and contains white to punk zoned feldspar phenocrysts, black garnet, and aegirineaugite. The feldspar phenocrysts may be larger than in the nongarnetıferous variety, generally about one-eighth of an inch but as much as half an inch long, and are more abundant and constitute about 50 percent of the rock. The aegirme-augite commonly occurs as small blades that are altered to hydrous iron oxides, and the garnet occurs as round grains, approximately one-sixteenth of an inch in diameter, that also are altered to the same oxides. Some specimens are altered to shades of dark gray; others are altered to 
pale pinkish gray. Weathered specimens of the rock are a darker reddish brown than the fresh rock.

The groundmass of the garnetiferous bostonite porphyry is similar to that of the bostonite porphyries. Euhedral to subhedral phenocrysts of compositionally zoned oligoclase-albite in the form of laths and plates constitute most of the feldspar phenocrysts. Characteristically, the feldspar is twinned according to the periclinealbite twin laws. The smaller oligoclase-albite phenocrysts-those less than $3 \mathrm{~mm}$ long-have sharp, straight crystal faces, whereas those that are about $2 \mathrm{~cm}$ long and which show euhedral growth zones have sutured boundaries because each of these larger crystals has an overgrowth of potassic feldspar that is intergrown with the feldspar laths of the groundmass. The plagioclase near the margins of the larger crystals is more albitic than the smaller crystals. Untwinned albite crystals are small equidimension subhedral to anhedral phenocrysts. Potassic feldspar usually does not occur as individual grains but instead is an overgrowth of the plagioclase, as described above. The garnet forms euhedral crystals that range from 05 to $1.5 \mathrm{~mm}$ in diameter. X-ray and index of refraction determinations show the garnet to be andraditic (Harrison and Wells, 1956). Sphene and aegirine-augite crystals commonly are inclusions in the garnet. The aegirme-augite also occurs as small anhedral grains in the groundmass and as euhedral bladed phenocrysts as much as $1.5 \mathrm{~mm}$ long. The accessory minerals are sphene, apatite, and zircon. Specimens from half a mile east of Dumont contain carbonate, epidote, and chlorite as alteration products.

The mineral composition of the garnetiferous bostonite porphyry is simular to that of the bostonite porphyry, but plagioclase is more abundant and generally constitutes nearly 45 percent of the rock, and quartz is less abundant. Garnet characteristically makes up about 5 percent of the rock by volume.

\section{TRACHYTIC GRANITE PORPHYRY}

Trachytic granite porphyry is exposed as a series of dikes in the vicinity of Lawson (pl. 19) and along Chicago Creek and lower Spring Gulch; a single northwestward-striking dıke is exposed on the north side of Pewabic Mountain. The dike series near Lawson consists of a wide northward-trending dike and narrow eastwardand northward-trending dikes. Along Chicago Creek and lower Trail Creek, the dikes are of varying length, but they are generally long, narrow, northeastward-trending dikes.

The trachytic granite porphyry is serlate porphyritic and has an aphanitic pale-red to reddish-brown groundmass. It contains pink to white feldspar phenocrysts and at places small phenocrysts of a ferromagnesian mineral. Two phases of this rock can be distin- 
guished on the basis of the feldspar phenocrysts which vary in size, quantity, and crystal habit. A coarse-grained phase contains rounded phenocrysts which are as much as three-fourths of an inch long and which constitute about 25 percent of the rock. A relatively fine-gramed phase contains both lathlike and subrounded phenocrysts that are as much as one-fourth of an inch long and constitute about 10 percent of the rock. The rock has an irregular granular-appearing fractuie. Upon weathering, the rock becomes either a darker or lighter red.

The trachytic granite porphyry closely resembles the bostonite porphyry because of the color of the groundmass and its general appearance, especially the finer gramed phase; and the two can be distinguished only with the ald of a microscope. The phenocrysts of the trachytic granite porphyry resemble those in bostonite, and the groundmass is characteristic of that in quartz bostonite.

Microscopically, the groundmass is hypidiomorphic granular, and it consists of stubby, euhedral to subhedral plagioclase laths, subhedral potassic feldspar grains, and anhedral quartz grains that fill the interstices between the feldspar grains. Most specimens tend to have subhedral plagioclase laths, but specimens from dikes along Chicago Creek show conspicuous euhedral laths.

The size of the groundmass grains range from 002 to $0.1 \mathrm{~mm}$ in length; the samples with euhedral plagioclase contain grains as large as $03 \mathrm{~mm}$ Most of the plag1oclase phenocrysts are euhedral plates and crystal aggregates, as much as $1.5 \mathrm{~mm}$ in length, which are compositionally zoned from middle oligoclase in the center to albite on the margins. Pericline and albite twinning are generally present but poorly formed. Some of the specimens of the finegrained phase have phenocrysts of zoned, untwinned albite. Phenocrysts of orthoclase occur as plates and crystal aggregates as large as $3 \mathrm{~mm}$. Euhedral pseudomorphs, 08 to $15 \mathrm{~mm}$ long, of quartz, magnetite, and clay minerals replace a ferromagnesian mineral. Euhedral grains of sphene are altered to magnetite-1lmenite and leucoxene. Accessory minerals are sphene, magnetite-ilmenite, apatite, and zircon.

The approximate estımated range of mineral composition of the trachytic granite porphyry is 5 to 15 percent quartz, 20 to 40 percent plagioclase, 45 to 65 percent potassic feldspar, as much as 5 percent ferromagnesian mineral, and trace amounts of the accessory minerals. The samples that contain the large phenocrysts also contain the most plagioclase.

\section{QUARTZ BOSTONITE PORPHYRY}

The quartz bostonite porphyry occurs as long, thin steeply dipping, branching dikes that locally extend from small plutons or 
plutonlike centers. Some of the dikes are several miles in length. Near Central City (pl. 19) the dikes strike northwest and northeast to form a prominent grid pattern; shorter dikes, which have essentially the same strike but do not form a grid pattern, occur in the lower Spring Gulch area along Chicago Creek. From lower 'Trail Creek west to the map boundary, the dike direction is predominantly eastward; but some dikes trend north, northeast, and northwest.

The quartz bostonite porphyry has a aphanitic groundmass of various shades of lilac, and it contains variable quantities of phenocrysts, ranging from 0 to about 25 percent. The less porphyritic phases have a groundmass that is pale red purple to grayish purple, whereas the more porphyritic phases are pale red; with bleaching or alteration, which are common in these rocks, the color grades to vely light gray and locally to chalky white. The phenocrysts are mostly pink to gray feldspar crystals, generally less than one-fourth of an inch long, which occur as individuals and irregular aggregates. The phenocrysts are commonly altered to gray green or white clay minerals Some specimens show small rounded areas of hydrous iron oxides, probably formed by the alteration of magnetite. In some specimens the grains in the groundmass are large enough that the trachytic texture can be seen with the ald of a hand lens.

- Microscopically, the groundmass has a bostonitic texture and consists of quartz and long, slender feldspar laths, probably anorthoclase. The laths are subhedral to anhedral, commonly show carlsbad twinning, and range in length from 0.1 to $0.3 \mathrm{~mm}$; chilled margins have smaller grains. The quartz forms anhedral grains between and around feldspar laths. In some specimens, which contain abundant quartz, the characteristic texture formed by the interlocking feldspar laths is partly destroyed because of the separation by quartz grains. In some specimens minute grains of a black opague mineral are scattered through the groundmass. The feldspar phenocrysts are euhedral to subhedral crystals and aggregates of carlsbad-twinned anorthoclase $\left({ }^{2}\right)$. The crystals range from 1 to 3 $\mathrm{mm} \mathrm{m}$-length. Magnetite grains as much as $1 \mathrm{~mm}$ in diameter are present in some specimens, particularly from the lower Spring Gulch area of Chicago Creek. These grains are commonly replaced by hydrous iron oxides and quartz. Accessory minerals are apatite, zircon, and rarely fluorite and carbonate.

The quartz bostonite porphyry has an estimated mineralogic composition ranging from 10 to 25 percent quartz, 70 to 80 percent anorthoclase(?), and 0 to 10 percent magnetite. Trace amounts of the accessory minerals are present. 


\section{HORNBLENDE GRANODIORITA GROUP}

The members of the hornblende granodiorite group-hornblende granodiorite porphyry, biotite granodiorite porphyry, biotite-quartz monzonite porphyry, and biotite-quartz latite porphyry-are classed together because they contain biotite or other ferromagnesian minerals, generally contain more calcic plagioclase than any of the other intrusive rocks, and are closely associated geographically.

The hornblende granodiorite and the biotite granodiorite porphyries can be distinguished in hand specimen by the presence of their respective ferromagnesian minerals. The biotite-quartz latite and biotite-quartz monzonite porphyries are distinguished from the granodiorites microscopically by their lower ratio of plagioclase to potassic feldspar and megascopically by the presence of quartz phenocrysts in the form of bipyramids on the monzonite and the presence of small sparse quartz phenocrysts in a very fine-grained groundmass in the latite porphyry. (See table 1 for a summary of the petrographic characteristics of the group.)

\section{HORNBLENDE GRANODIORITE PORPHYRY}

Hornblende granodiorite porphyry is exposed as an irregular pluton about 3,500 feet long and 2,500 feet wide along Fall River in the central part of the area (pl. 19). Large bodies of country rock are included in the pluton, but small fragments are not known to be present in the body. Most of the pluton is a seriate porphyritic rock that is gray with black flecks; the rock consists essentially of plagioclase, orthoclase, quartz, and ferromagnesıan minerals. Crystals of sphene can be recognized megascopically in some specimens. A few large feldspar phenocrysts about three-fourths of an inch long are conspicuous, but the smaller plagioclase phenocrysts are inconspicuous; thus those parts free from the large phenocrysts appear to be medium grained. The ferromagnesian minerals are scattered through the groundmass with feldspar and quartz. Some of the pluton consists of a seriate porphyritic rock that has a meduum-gray aphanitic groundmass and conspicuous light-gray rounded feldspar phenocrysts as much as three-eighths of an inch long, which constitute about 40 percent of the rock. The weathered surface is light gray.

Microscopically, the texture of the hornblende granodiorite porphyry is hypidiomorphic granular; the phase that contains smaller, more abundant phenocrysts has a fine-grained allotriomorphic granular groundmass. The large, 5 to $15 \mathrm{~mm}$, phenocrysts are untwinned unzoned albite. Oligoclase occurs as euhedral to subhedral crystals that have sutured boundaries with the fine-grained groundmass and range from $0.01 \mathrm{~mm}$ to $5 \mathrm{~mm}$ in length. Compositional zoning in the 
plagioclase ranges from calcic oligoclase in the center to sodic oligoclase at the margins. The crystals generally consists of several parts that have a slightly different orientation. Pericline and albite twinning either alone or in combination is common, whereas combinations with carlsbad twinning are uncommon. Orthoclase occurs as subhedral to anhedral grains ranging from $001 \mathrm{~mm}$ to $25 \mathrm{~mm}$ in length situated between the larger plagioclase grains. The orthoclase is perthitic, and some grains show carlsbad twinning. Irregular patches of orthoclase are enclosed by the large albite grains. Two ferromagnesian minerals-hornblende and a pyroxene that is probably augite - are present in this rock. The hornblende occurs in euhedral to subhedral laths that range from 0.1 to $2 \mathrm{~mm}$ in length. Some grains have been replaced by fine-grained aggregates of biotite and magnetite, possibly during the hydrothermal stage, for veinlets of quartz and grains of pyrite and calcite are associated with the biotite. The augite occurs as euhedral to subhedral crystals, ranging from 0.5 to $2.0 \mathrm{~mm}$ in length, associated with the hornblende. Quartz is in anhedral grains as much as $1 \mathrm{~mm}$ across that fill the spaces between other grains. Some of the quartz probably was introduced during the hydrothermal stage.

Accessory minerals are sphene, apatite, topaz, magnetite-ilmenite, allanite, calcite, pyrite, zircon, epidote, and serpentine. The sphene occurs in unusually large euhedral twinned crystals as much as 15 $\mathrm{mm}$ in length. Calcite and pyrite are not present in all samples but occur together with quartz veinlets. Epidote and serpentıne are uncommon alteration products of the ferromagnesian minerals.

Approximate modal analyses show that the hornblende granodiorite contains approximately 5 to 30 percent quartz, 40 to 75 percent plagioclase, 15 to 20 percent orthoclase, 0 to 5 percent albite, 3 to 8 percent hornblende, 0 to 3 percent augite, and trace amounts of the accessory minerals.

\section{BIOTITE GRANODIORITE PORPHYRY}

Biotite granodiorite porphyry is exposed as a pluton about 1,500 feet long and 600 feet wide and as short dikes between Spring Gulch and Fall River in the central part of the area, and as a small body near the western boundary of the area (pl 19).

The biotite granodiorite porphyry is a light-greenish-gray seriate porphyritic rock with conspicuous black flakes of biotite. The quartz is in rounded grains as large as one-fourth of an inch in diameter. The feldspar occurs as pinkish laths as much as an inch long and as smaller, inconspicuous gray grains. Biotite is present as books and flakes among the other minerals. The weathered surface- is light gray. 
Microscopically, the texture of the biotite granodiorite porphyry is hypidiomorphic granular. The three feldspars present in the rock are albite, oligoclase, and orthoclase. The large pinkish phenocrysts seen in hand specimen are untwinned subhedral albite crystals that have inclusions of small quartz grains around the margins. Anhedral grains of albite, $0.02 \mathrm{~mm}$ or less in diameter, occur in the groundmass. Oligoclase to sodic oligoclase occurs as anhedral to subhedral crystals and aggregates that show zoning and combined carlsbad-albite-pericline twinning. Single crystals range in diameter from 0.1 to $5 \mathrm{~mm}$ and aggregates range up to $1 \mathrm{~cm}$ in diameter. Orthoclase forms anhedral grains 0.1 to $1 \mathrm{~mm}$ across which show carlsbad twinning and generally are more altered to clay than the other feldspars. Quartz occurs as anhedral rounded grains with sutured boundaries and ranges from 0.01 to $3 \mathrm{~mm}$ in diameter. The biotite occurs as subhedral to anhedral crystals with irregular boundaries caused by embayment by quartz grains. The biotite crystals range in length from 0.5 to $1.5 \mathrm{~mm}$.

Accessory minerals are sphene, apatite, magnetite-ilmenite, and zircon. Much of the sphene has been altered to leucoxene.

Two modal analyses of samples of biotite granodiorite porphyry show the composition to be quartz, 31 and 34 percent; orthoclase, 8 and 17 percent; albite, 11 and 12 percent; oligoclase, 48 and 34 percent; biotite, 3 and 3 percent.

\section{BIOTITE-QUARTZ MONZONITE PORPHYRY}

Biotite-quartz monzonite porphyry occurs as a single eastwardtrending dike, about 2 miles long, north of Dumont (pl. 19). The porphyry has a light-gray aphanitic groundmass; the phenocrysts are yellowish-gray feldspar, clear quartz, some of which is bipyramidal, and brotite in books and flakes. The feldspar and quartz phenocrysts are generally less than one-fourth of an inch long and the biotite less than one-sixteenth of an inch long. The phenocrysts constitute about 30 percent of the rock. The weathered surfaces are very light gray, and the quartz phenocrysts stand out prominently.

Microscopically, the groundmass is allotriomorphic granular, and it consists essentially of quartz and potassic feldspar. Both minerals are anhedral and range in diameter from 0.01 to $0.1 \mathrm{~mm}$. Carbonate is present between the larger grains as small irregular areas in the groundmass The feldspar phenocrysts are euhedral laths and aggregates that range from 02 to $3 \mathrm{~mm}$ in length. Most of the crystals have pericline-albite twinning. A considerable amount of clay has replaced the oligoclase. The quartz crystals are euhedral with some showing embayment of groundmass into the quartz; the length ranges from 0.2 to $2 \mathrm{~mm}$. The biotite crystals 
are euhedral and range from 0.1 to $1 \mathrm{~mm}$ in length; chlorite and magnetite have completely replaced most of the grains. Accessory minerals are apatite, sphene, magnetite-ilmenite, zircon, and allanite.

The composition of the biotite-quartz monzonite porphyry is approximately 25 percent quartz, 45 percent potassic feldspar, 25 percent oligoclase, and 5 percent biotite. Trace amounts of the accessory minerals are present.

\section{BIOTITE-QUARTZ LATITE PORPHYRY}

Exposures of biotite-quartz latite porphyry are limited to the area immediately west of Idaho Springs along Chicago Creek and to the slope a mile southwest of Lawson (pl. 19). All the dikes strike northeast, except near Lawson where some trend northwest. A series of short dikes occur south of the junction of Trail and Clear Creeks, and two longer dikes extend westward nearly parallel to Chicago Creek. Biotıte-quartz-latite dikes are exposed in underground workings of the Dorit, King Solomon, Stanley, Lincoln and Donaldson mines, west of Idaho Springs; some of these dikes have no known surface exposure.

Two textural phases of biotite-quartz latite porphyry, both of which locally show well-developed flow layering espeically along the margins, are recognized. One phase is very fine grained and contains sparse phenocrysts, and the other is coarser grained and contains relatively abundant phenocrysts. The very fine grained phase has a greenısh-gray to dark-gray aphanitic groundmass; phenocrysts consist of biotite flakes and books and urregular feldspar crystals as much as one-sixteenth of an inch across. The phenocrysts constitute about 5 percent of the rock. An irregular to smooth conchoidal flinty fracture is characteristic of the fine-grained phase. This phase weathers to a reddish tan. The fresh coarser grained phase has a brown-gray aphanitic groundmass and contains white feldspar phenocrysts that constitute from about 20 to 50 percent of the rock. The feldspar laths are generally less than one-sixteenth of an inch long but may be as much as half an inch long. Biotite books and flakes are scattered through the rock. The coarser phase weathers to a light gray. Two of the coarser grained dikes, one of which shows conspicuous flow layering, have been profoundly altered; the color has been changed to yellowish gray; and the biotite has been replaced by limonitıc material. The dike having a conspicuous flow layering crops out near Trail Creek; the other is the longest dike along Chicago Creek.

Microscopically, the groundmass ranges in texture from allotriomorphic granular in the very fine grained or cryptocrystalline phase 
to hypidiomorphic granular in the coarser grained or microcrystalline phase. The groundmass consists essentially of olıgoclase-andesine, potassic feldspar, and quartz. The cryptocrystalline phase has a felty appearance caused by conspicuous crudely alined oligoclaseandesine laths. The grain size ranges from cryptocrystalline to $0.1 \mathrm{~mm}$. In the groundmass the plagioclase is in euhedral to subhedral laths; the potassic feldspar in subhedral to anhedral grains; and the quartz in anhedral grains. The groundmass of the microcrystalline phase ranges in size from 0.02 to $0.1 \mathrm{~mm}$. The plagioclase grains are equidimensional and not conspicuous; otherwise the groundmass of the two phases is essentially the same. The oligoclase-andesine phenocrysts, ranging in size from 0.3 to $2 \mathrm{~mm}$, are euhedral to subhedral laths and plates which have albite twinning occurring alone or in combination with pericline or carlsbad twining. The plagioclase in the coarser or microcrystalline phase tends to be more sodic than in the finer grain phase. Subhedral biotite laths and books range in size from 03 to $1 \mathrm{~mm}$. In the altered specimens the biotite is replaced by hydrous iron oxides, magnetite, quartz, and chlorite. In some specimens a few rounded quartz phenocrysts, about $05 \mathrm{~mm}$ in diameter, are present.

The approximate estimated mineral composition of the biotitequartz latite porphyry is 35 percent quartz, 40 percent plagioclase, 20 percent potassic feldspar, and 5 percent biotite. Accessory minerals are apatite, magnetite-1lmenite, sphene, and zircon.

\section{ALTERATION}

The Tertiary intrusive rocks are altered to varyıng degrees. Generally the ferromagnesian minerals are completely changed, and the feldspars partly changed to secondary minerals, but at places these minerals are only partly altered.

The alteration is pervasive; and, although the rocks that constitute the walls of vein-fissures generally are more intensely altered than those more distant from veins, all rocks are altered to some degree. Generally the feldspars and ferromagnesian minerals are changed to clay minerals and sericite, but at places they are changed to epidote, calcite, and chlorite. The development of clay minerals changes the color of the rocks to gray, whereas the saussuritic alteration changes it to a dark greenish gray.

As the Tertiary igneous rocks in all environments are always more altered than the adjacent crystallıne rocks, the writer believes that the alteration largely resulted from late magmatic or deuteric solutions. At places, later hydrothermal solutions intensified the alteration in the vein environment. 

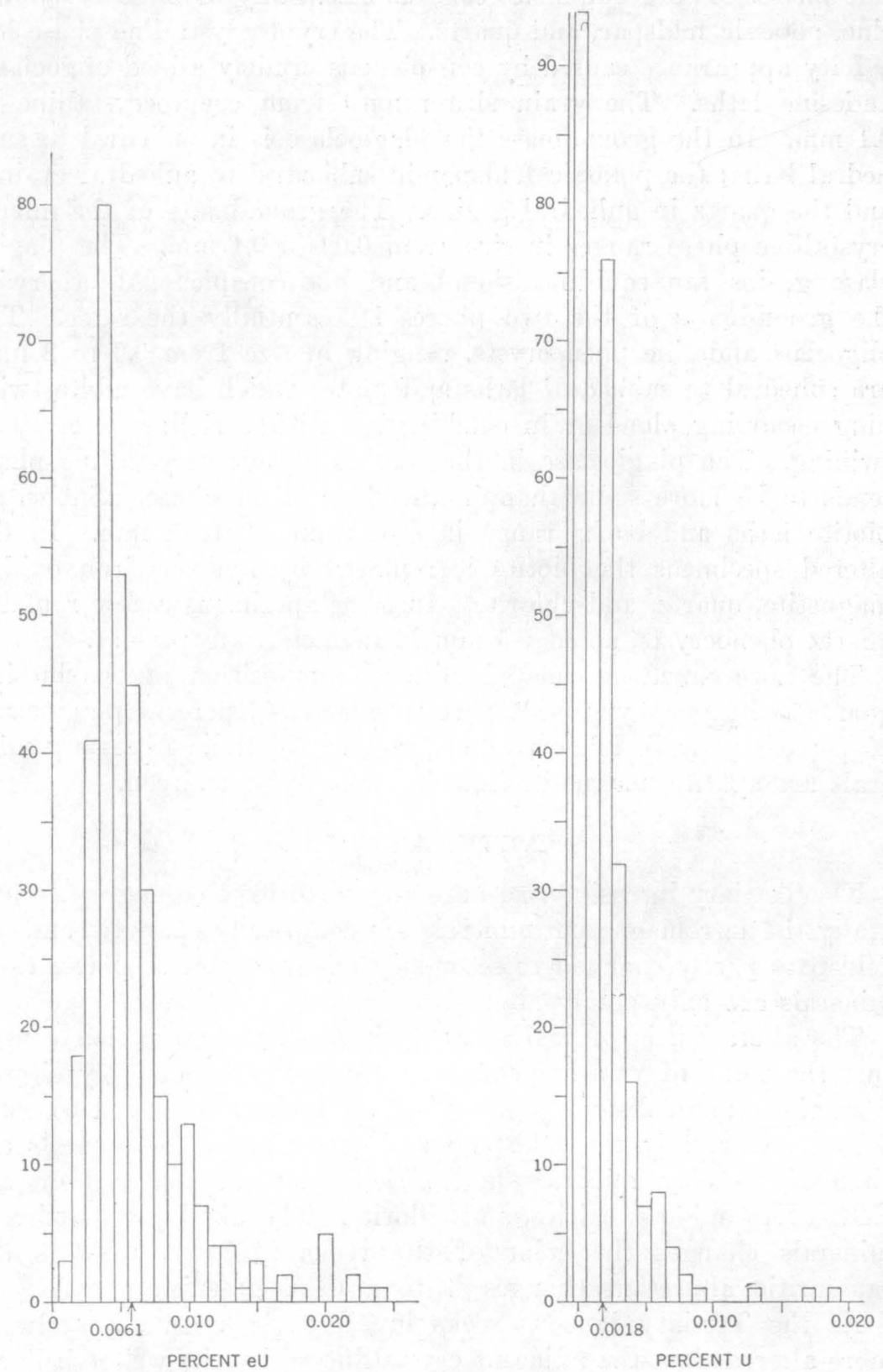

FigURE 59.-Histograms showing distribution of radioactivity (equivalent uranium) and uranium in all Tertlary igneous rocks, central part of Front Range mineral belt, Colorado. 


\section{RADIOACTIVITY AND URANIUM IN THE IGNEOUS SEQUENCE}

The Tertiary igneous sequence of the region is one of the most radioactive groups of intrusive rocks in the world, according to the present literature. All the rocks are more radioactive than the average granitıc rock of Keevll (Phair, 1952, fig. 2); and quartz bostonite porphyry, the most radioactive rock of the sequence, is 15 to 25 times as radioactive as the average granitic rock (Phair, 1952 , p. 25).

The work of Phair (1952) has shown that the radioactivity of the rock results from both thorium and uranium, which are essentially in equilibrium with their daughter products, and that these metals are primary constituents of the rock, occurring in part in the mineral zircon. He further has shown (p. 26) that the ratios of thorium to uranium in the least altered quartz bostonite porphyry averages about 6.4 and seems to be fairly constant from dike to dike.

The radioactivity and the uranium content of all Tertiary in. trusive rocks of the region are shown in the histograms on figure 59. The histograms show the frequency of occurrence and distribu. tion of values of radioactivity and uranium content as well as the arithmetic average of these values for all the Tertiary intrusive rocks, each of the groups, and the individual rock types that constitute the groups. Although a large proportion of the samples were reported to contain no uranium because the sensitivity limit for standard chemical uranium determinations is 10 parts per million, many of this group probably contain a few parts per million uranium.

The rocks constituting the igneous sequence contain an average of 0.0061 percent equivalent uranium and 0.0018 percent uranium, but vary widely from these figures (fig. 59). The values of both equivalent uranıum and uranıum with respect to the averages are low in all except the youngest rocks. The average equivalent uranium and uranium content of the hornblende granodiorite (fig. 60), light-colored granodıorite (fig. 61), and quartz monzonito (fig. 62) groups is below the average of all the rocks of the sequence, whereas the averages of the bostonite group (fig. 63) aro above the average for all rocks. The variations in average values for the equivalent uranium and uranıum content of each rock type is graphically shown in figure 64. These, arranged according to age within each group, show an increase in uranium and equivalent uranium content from the oldest to the youngest members of each group. The values for uranium and equivalent uranium are generally lower for the hornblende granodiorite group than for the others. 

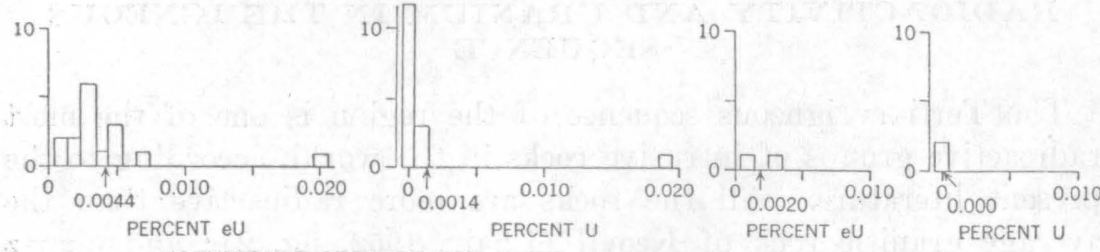

HORNBLENDE GRANODIORITE GROUP

HORNBLENDE GRANODIORITE
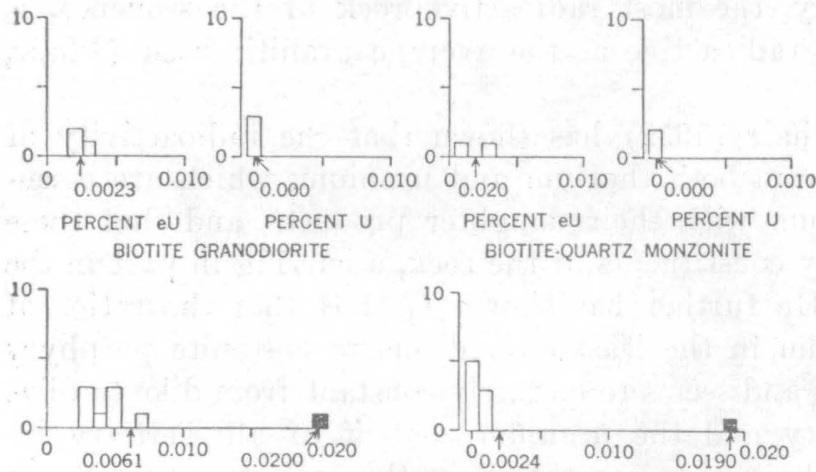

PERCENT EU

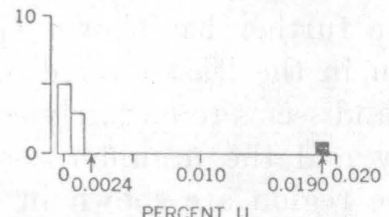

BIOTITE.QUARTZ LATITE

Figure 60.-Histograms showing distribution of radioactivity (equivalent uranium) and uranium in the hornblende granodiorite group. Blackened areas indicate unusual samples discussed in text.
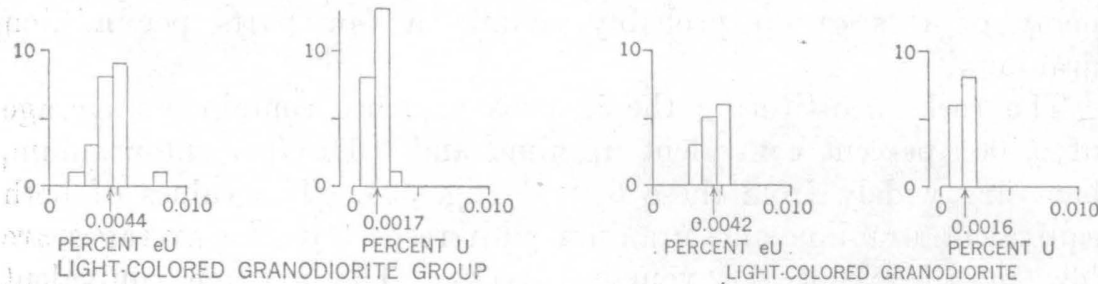

LIGHT.COLORED GRANODIORITE GROUP

LIGHT.COLORED GRANODIORITE
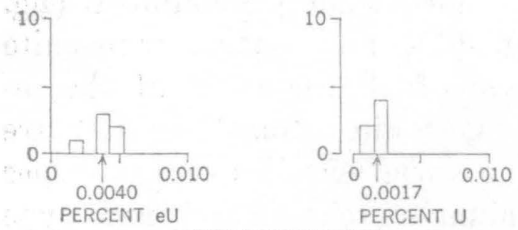

ALBITE GRANODIORITE
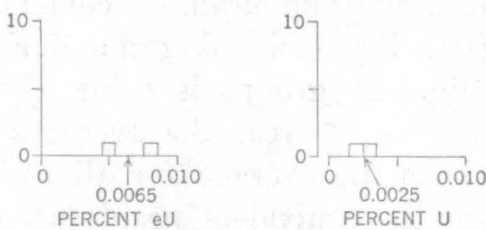

ALKALIC SYENITE

FIGURE 61.-Histograms showing distribution of radioactivity (equivalent uranium) and uranium in the light-colored granodiorite group. 

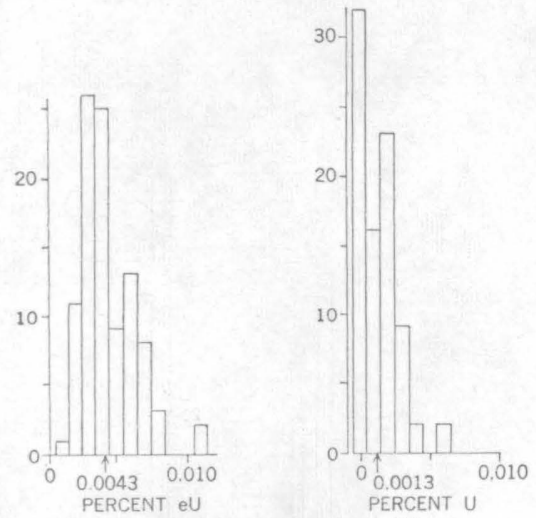

QUARTZ MONZONITE GROUP
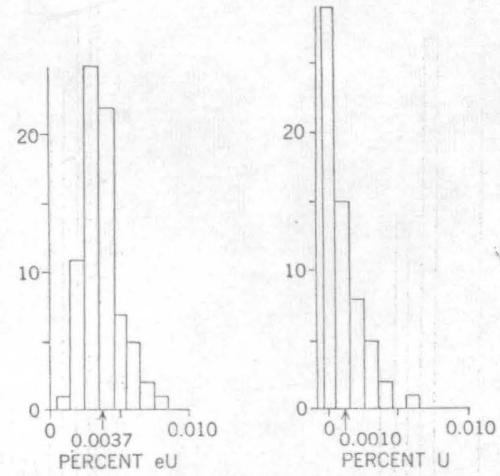

QUARTZ MONZONITE
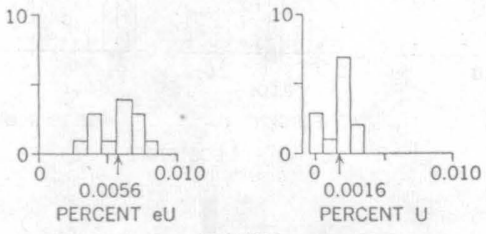

GRANITE
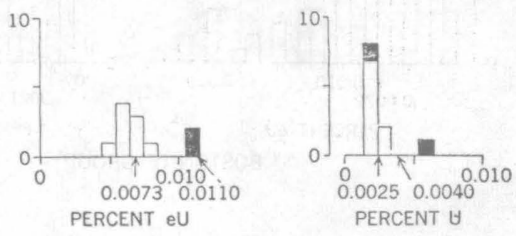

Figure 62.-Histograms showing distribution of radioactivity (equivalent uranium) and uranium in the quartz monzonite group. Blackened areas indicate unusual samples discussed in text.

The quartz bostonite dikes of Prosser Gulch and Nigger Hill, the youngest quartz bostonites in the Central City district, contain unusually large amounts of equivalent uranium and uranium; samples from these dikes are shown by blackened parts of the histograms in figure 63. Some samples from the youngest members of the quartz monzonite and hornblende granodiorite groups have unusually high radioactivity for their respective rock types. Two such samples of alaskite porphyry (blackened part of histograms fig. 62), one from the small pluton north of and one from the dike south of Alps Mountain, present respectively one of several taken from each of the two bodies. A highly radioactive sample of biotitequartz latite porphyry was taken from the Donaldson mine in the lower Trail Creek area (blackened part of histogram fig. 60). Although the alaskite porphyry samples may have been contaminated by hydrothermal solutions which deposited uranium nearby, the biotite-quartz latite sample was taken several thousand feet from known uranium deposits.

Postconsolidation alteration did not appreciably change the amount of equivalent uranium (measured radioactivity) or uranium in the rocks nor did it materially affect the ratio of equivalent uranium 


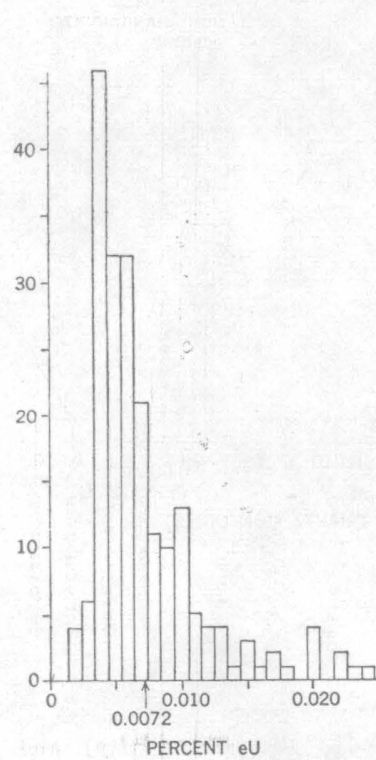

BOSTONITE GROUP

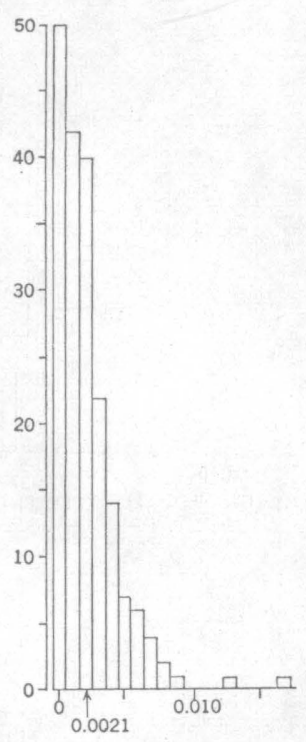

PERCENT U
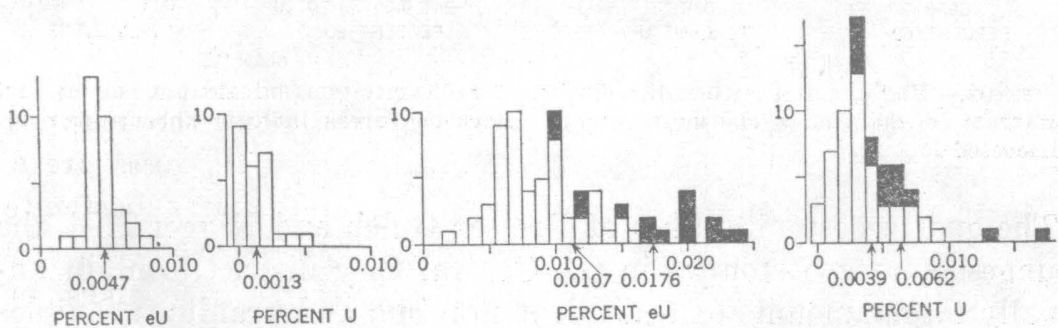

TRACHYTIC GRANITE

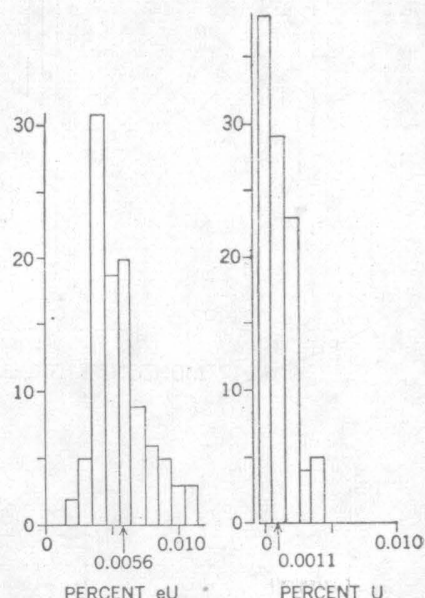

BOSTONITE

FIGURB 63.-Histograms showing distribution of radioactivity (equivalent uranium) and uranium in the bostonite group. Blackened areas indicate unusual samples discussed in text.

to uranium. Except locally in the Central City district (Phair, 1952, p. 44), there is no apparent correlation between the degree of alteration and the equivalent uranium and uranium content of a rock. If alteration had materially affected the quantities of the radioactive elements in the rocks, the relatively leachable uranium should have been preferentially leached; this would change the ratio of uranium to equivalent uranium. Such is not the case, for although both the altered and the relatively unaltered phases of the rocks have a wide range of radioactivity and of uranium content, most of the samples of each rock type have within the limits of analytical error approximately the same ratio of equivalent uranium to uranium. Those ratios that are erratic show no relation to the degree of alteration. 


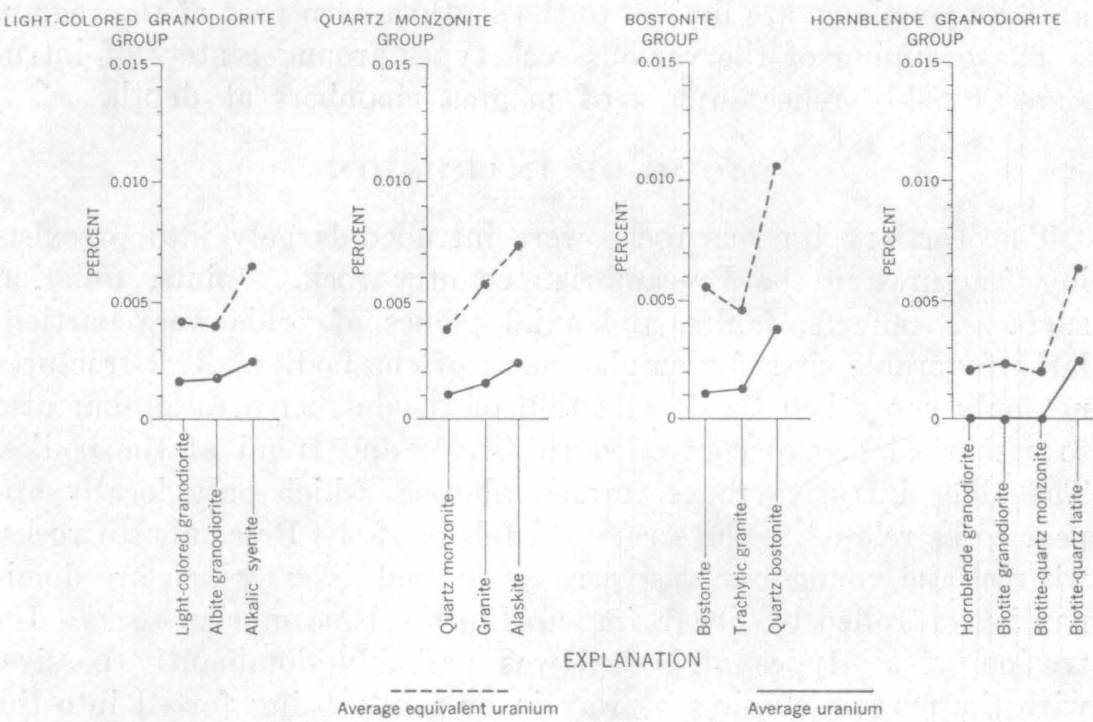

Frgure 64.-Diagram showing variations of equivalent uranium (radioactivity) and uranium with rock type arranged in order of decreasing age within groups.

\section{DISTRIBUTION}

Although some rock units are present throughout the mapped region (pl. 19), others are limited to relatively small, local areas.

The quartz monzonite, granite, bostonite, and quartz bostonite porphyries occur throughout the region but are characteristically grouped around centers of radiating dikes, intersecting dikes, or plutons. Quartz bostonite porphyry and bostonite porphyry form conspicuous centers on Nigger Hill, Kings Flat, and Quartz Hill that result from two or more intersecting dikes. The quartz bostonite porphyry dikes on Pewabic Mountain extend outward from a small pluton on the north slope of the mountain; another prominent, branching dike of the same rock type extends from a small plutonic center south of Dumont. Quartz monzonite dikes are locally abundant, as in the area north of Idaho Springs, and generally are particularly common near a large pluton of the rock, as on the south slope of Bellevue Mountain. Irregularly branching dikes of garnetiferous bostonite porphyry, a distinctive phase of the bostonite porphyry, are abundant in the upper Trail Creek area.

The light-colored granodiorite group, hornblende granodiorite group, trachytic granite porphyry, and alaskite porphyry have a limited geographic occurrence. The light-colored granodiorite group is found only in the eastern part of the area; and the hornblende granodiorite porphyry occurs only in the northwestern part, mainly in the lower Fall River area. The trachytic granite porphyry and 
alaskite porphyry are limited to the southwestern part of the region.

The grouping of the various rock types around centers of intrusion probably reflect apices of magma chambers at depth.

\section{MODE OF INTRUSION}

The Tertiary igneous rocks were intruded largely into preexisting fractures in the Precambrian country rock. Joints, follation surfaces, contacts, faults, and axial planes of folds were particularly favorable sites for emplacement of the bodies. The fractures not only controlled the localization of the intrusive rocks, but also to a marked degree controlled the shape and trend of the bodies. The older intrusive rocks formed plutons, which only locally appear to be related to the structural fabric of the Precambrian rocks, whereas the younger intrusive rocks formed dikes, which are dominantly controlled by linear fractures in the Precambrian rocks. Intrusion of all types of bodies was probably dominantly passive, with the magma stoping its way in or rarely being forced into the fractures that offered the least resistance to its movement. Intrusion breccias are associated with some of the plutons and probably resulted from local explosive force.

At many places throughout the region, it can be demonstrated that the igneous bodies are localized by joints, folıtion surfaces, axial planes of tight folds, faults, and contacts Many dikes trend parallel to well-defined joint sets and in detail are seen to occur in particular joints A close correlation between dikes and joint sets is particularly striking in the Central City district. The intersecting northwestward-trending and northeastward-trending quartz bostonite porphyry dikes, which form a prominent grid pattern in the Central City district (pl. 19), respectively occupy northwestwardstriking and northeastward-striking joints. In detall, however, the dikes within each of the dike groups, occur in two or more specific joint sets (Sims, Osterwald, and Tooker, 1955, p 11; Sims, Drake, and Tooker, written communication, 1957). Foliation, surfaces and axial planes of tight folds are the dominant structural features controlling the localization of dikes in the Chicago Creek area (Harrison and Wells, 1959), and probably also the southern part of the Idaho Springs district (Moench and Drake, written communication, 1957). In these areas the dikes trend mainly northeastward, parallel to the prevailing structural fabric of the Precambrian country rock On Bellevue Mountain a large body of quartz monzonite porphyry occurs at the contact between two Precambrian rock units and possibly is a laccolith (pl. 19). Along the Chicago Creek dikes follow contacts for short distances. Dikes of quartz monzonite porphyry and bostonite porphyry locally occur 
along the Idaho Spring fault, west of Idaho Springs. Dikes of biotite-quartz latite porphyry follow vein fissures along part of their length.

The localization of the igneous plutons by earlier structural features is not conspicuous, but most of these bodies are elongate parallel to a conspicuous joint direction. Most plutons in the eastern part of the region (pl. 19) are elongated in a northeast direction, subparallel to a prominent joint set. Commonly, dikes associated with these bodies extend outward from the margins of these bodies in the same direction.

Although all the intrusive bodies were largely localized by preexisting planar structural features in the Precambrian bedrock, the influence of these features on the shape of the bodies was more pronounced in the younger members of the sequence. The earlier intrusive rocks, as the hornblende granodiorite group, formed moderate-sized irregular-shaped bodies with only rare associated short dikes; the slightly younger intrusive rocks of the quartz monzonite group and the biotite-quartz monzonite porphyry formed small irregular bodies with associated long branching dikes; and the youngest intrusive rocks, the bostonite group and the biotite-quartz latite porphyry, almost exclusively formed long, thin continuous dikes. Rarely, small bulbous bodies developed along the younger dikes.

Intrusion breccias consisting of wallrock fragments in a matrix of igneous rock are associated with plutons of light-colored granodiorite porphyry and quartz monzonite porphyry in the Central City district. The wallrock fragments differ in size, angularity, and abundance. Generally, they range from mappable blocks to microscopic fragments; they are rounded to angular; and they are sparse to abundant in the plutons of partly brecciated light-colored granodiorite porphyry and are abundant in the pluton of largely brecciated quartz monzonite porphyry in Chase Gulch. Most of the larger blocks probably were the result of stoping, but the fragmentation necessary to produce the smaller fragments was most likely the result of explosion.

The Patch, on Quartz Hill, is an oval-shaped breccia pipe consisting of intricately fractured, altered, and mineralized wallrock without an igneous matrix. Possibly this breccia formed by explosive activity above a "plug" of magma (Sims, Drake, and Tooker, written communication, 1957).

It is inferred from the nature of the breccias, the relation of the fragments to the matrix, and the form of the intrusive igneous bodies that the breccias were formed at different levels in the earth's crust; and by analogy with classical explosion pipes (Walker, 1928), the present erosional surfaces of the plutons rep- 
resent different levels in an explosion pipe. If it is assumed that all the plutons were formed in a similar manner, the plutons of light-colored granodiorite porphyry with sparse breccia fragments represent a level low in the pipe, where most of the space was occupied by magma; the quartz monzonite porphyry pluton would be intermediate, at a position where brecciated wallrock would be abundant with only a small quantity of magma; and the Patch would represent a level high in the pipe where brecciation was intense above the magma level. As the granodiorite porphyry plutons, quartz monzonite porphyry plutons, and the Patch have been eroded to progressively lesser depths, the Patch is presumed to be the youngest of the breccias.

It is probable that local explosive activity initiated the intrusion of the magmas that consolidated to form light-colored granodiorite, quartz monzonite, and bostonite groups. The known intrusion breccias are restricted to bodies of light-colored granodorite porphyry and quartz monzonite porphyry; these porphyries were the first igneous rocks of their respective groups to be emplaced. By extrapolation the next intrusion breccia would occur with the bostonite porphyry, the first intrusive of the bostonite group The Patch may be inferred to be associated with bostonite porphyry, because the Patch is probably the youngest breccia. If this is true, then the breccias are associated only with rock types that constituted the earliest intrusive body of their respective groups; and the inference may be made that local explosion, resulting in intrusion breccias, "triggered" the intrusion of each group.

As the walls of the igneous bodies are neither displaced nor brecciated, except locally, it appears that the igneous rocks were largely intruded passively into relatively open fractures in the country rock. Presumably the walls of the fractures were forced apart by tensional forces of unknown origin that preceded or accompanied the magma emplacement. The local explosions that are inferred to have caused the volcanic breccias were probably the result of sudden release of gas pressure concentrated in the apex of a magmatic chamber; this is a process similar to that suggested by Walker $(1928$, p. 895). The pressure may have been released when the magmatic chamber approached so near the surface that the rock load was no longer sufficient to confine the pressure or when an intersection occurred between the magmatic chamber and some of the early Laramide faults described by Sims (1956, $\mathrm{p}$ 743).

The earlier formed bodies were more equidimensional and contained considerable quantities of inclusions, whereas the later intrusive bodies were long dikes essentially free from inclusions This is interpreted by the author to indicate that the early intrusions 
were accomplished mainly by stoping with local explosive activity along the fractures which controlled the position and shape of the pluton. Later, tensional forces opened fractures or tended to open incipient fractures. This tensional stress would have allowed the magma, under slight pressure, to open and occupy or create and occupy fractures. Similar mechanics of dike intrusion have been described by Anderson (1942, p. 22-28).

\section{ORIGIN OF THE IGNEOUS ROCKS}

Although the principal purpose of this report is the description of the field occurrence and petrography of the intrusive rocks, the data acquired during field and laboratory studies suggest an hypothesis of differentiation of these rocks that parallels in some aspects and differs in other aspects from that proposed by Lovering and Goddard (1938). Lovering and Goddard concluded that three rock series occur in this area. These are the diorite-quartz monzonite-alaskite series, an alkalıc series of drorite-syenite-bostonite, and a biotite-monzonite-latite series. The first "*** may be explained as the normal differentiation from mafic to silicic facies ***"; the second was explained by subtractive differentiation in the parent magma chamber to form the syenitic alkalic series; and the third was regarded as the $" * * * *$ last material to consolidate from a deep gabbroic magma in which equilibrium conditions existed essentially throughout consolidation."

The author infers that the rocks constituting the Tertiary igneous sequence in this area were derived from two magmatic sources that existed simultaneously. One yielded a "major series" including the light-colored granodiorite, quartz monzonite, and bostonite groups of rocks, the other yielded a "minor series" including the hornblende granodiorite group of rocks. The rocks of the major series can reasonably be inferred to have been derived from a relatively large, broad magmatic chamber, whereas the rocks of the minor series are inferred to have been derived from a smaller, more restricted magmatic chamber.

These inferences are based on field and petrographic evidence. The rocks of the minor series are limited geographically to the lower Fall River area, contain relatively large quantities of calcic oligoclase, and contain the ferromagnesian minerals hornblende, pyroxene, and biotite. The rocks of the major series contain generally abundant albite and potassic feldspars; the only characteristic ferromagnesian mineral identıfied was aegirine-augite. Notwithstanding the fact that the major magmatic chamber possibly had three subchambers or two periods of rejuvenation to yield the three groups, the evolution of the grain size of the rocks, shapes of 
the bodies, and radioactivity of the two series is parallel. The oldest members of each series occur in medium- to coarse-grained equidimensional plutons whlle the youngest members occur in very finegrained, long, continuous thin dikes. The radioactivity of the minor series is generally lower than that of the major series; both show systematic variations with age. (See following section for details.)

Aside from the physical features that prompted the classification of the rocks into a major and a minor series, the general scheme of magmatic differentiation from two separate sources simplifies the overall differentiation sequence. If only one source had been present, it would be necessary to account for the culmination of a long sequence of intrusion with biotite-quartz latite porphyry (of quartz. monzonite composition) immediately following the potassium-rich quartz bostonite. Simultaneous differentiation from two separate sources of somewhat different composition accounts for the intrusion of magmas of different composition at nearly the same time, as is exhibited in this area.

The rocks of the Tertiary igneous sequence were intruded during the Laramide uplift; and, as erosion stripped off some of the rock load during uplift, confining pressures were reduced and fractures were allowed to open more easily. This change in lithostatic pressure is indicated by the gradual change in form of the intrusive bodies from the nearly equidimensional granodiorite porphyry plutons to the long narrow dikes of the bostonite group and brotitequartz latite porphyry. The coarse crystalline texture of the earliest intrusive rock, the hornblende granodiorite, as contrasted to that of the later intrusive rocks, particularly the cryptocrystalline phase of the biotite-quartz latite, indicates a slow rate of cooling of the early magma at a position of considerable depth. These changes in texture and shape of the bodies show that the magmas were probably intruded into progressively shallower depths of the earth's crust.

\section{DIFFERENTIATION OF URANIUM AND THORIUM}

In consideration of the radioactive properties of the Tertiary igneous rocks and the geologic distribution of the uranium deposition relative to the location of centers of quartz bostonite intrusive bodies, the author believes that uranium and thorium were concentrated by magmatic differentiation into the late phases of the igneous activity and that uranium was transported to the sites of deposition by hydrothermal solutions mostly derived from the quartz bostonite porphyry. 
To illustrate the reasons for this belief the data shown in figure 64 is shown in figure 65 with the rock types arranged in their intrusive order shown in figure 58. The quartz bostonite dikes of the Prosser Gulch and Nigger Hill (designated PN in figure 65) are shown separately because of their unusually high radioactivity and uranıum content. Individual samples from the Prosser Gulch and Nigger Hill dikes are shown as blackened areas in the histograms in figures 62 and 63 .

In the 3 groups-light-colored granodiorite, quartz monzonite, and bostonite-that comprise the major magmatic series (fig. 65), the radioactivity and uranium content is progressively greater in each succeeding group; similarly the maximum values are progressively greater in each succeeding group. The hornblende granodiorite group, which comprises the minor magmatic series, shows a similar but smaller rate of increase in equivalent uranium and uranium. The quartz bostonite dikes of Prosser Gulch and Nigger Hill, designated (PN) in figure 65, are the youngest quartz bostonites in the Central City district and contain unusually large amounts of equivalent uranıum and uranium. The high average radioactivity and uranium content of these dikes indicate further enrichment in uranium in the latest rocks of the major magmatic series.

The consistent progression in radioactivity and uranium content are readily apparent according to the rock classification presented here. If these were plotted as one magmatic series, the variations would be random; therefore, the plausıbility of the existence of the two magmatic sources is enhanced.

The progressive increase in the radioactive elements in successively younger members of each rock group plus the concentration of most of these elements in the last members of each group (fig. 65) indicate that uranium and thorium were concentrated during differentiation of the magmatic series within the magmatic chambers. If differentiation occurred in the magmatic chambers and the enrichment contınued with the uranium entering a residual aqueous phase, the magmas forming any of the four groups could have provided a source for the uranium-bearing solutions that contributed to the uranium deposits of the region. However, suitable sites for deposition of uranium were not available until the vein fissures were formed after the consolidation of the quartz bostonites (figs. 58 and 65). Therefore, only the magmas of the quartz bostonite porphyry and biotite-quartz latite porphyry may be considered as possible sources of uranium mineralization.

The blotite-quartz latite magma could have been a minor contributor of uranium-bearing fluids to the vein fissures that were open prior to its intrusion or to those minor fissures that formed after 


\section{EXPLANATION}

Average equivalent uranium of the major series including the Lightcolored granodiorite, quartz monzonite, and bostonite groups

Average uranium of the major series

Average equivalent uranium of the minor series including the horn blende granodiorite group

Average uranium of the minor series

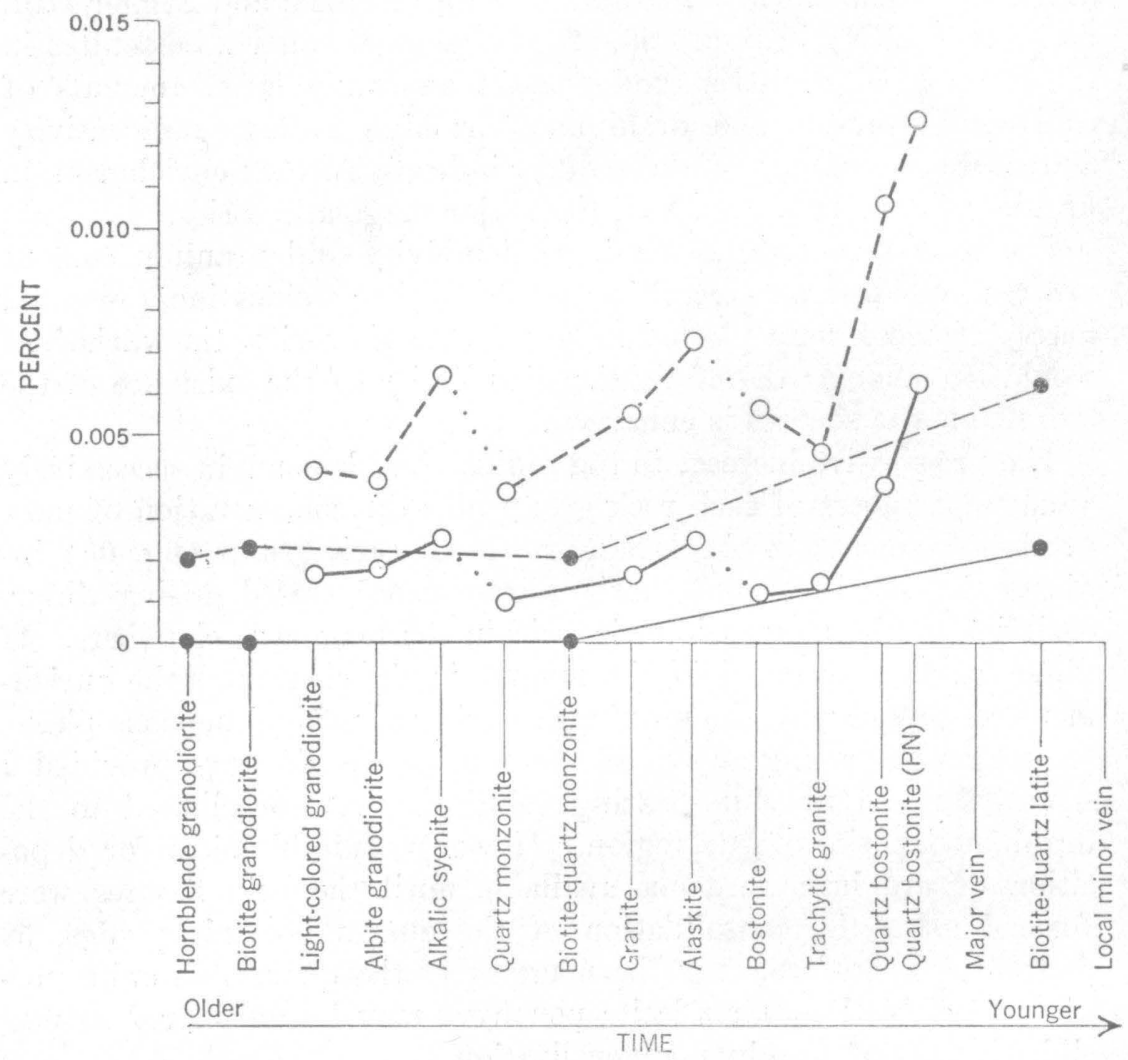

FIgURE 65.-Diagram showing variation of equivalent uranium (radioactivity) and uranium with rock type and time. Rock types are arranged in order of their intrusion, and the average value of each type is plotted on the vertical axis. Different members of each group are connected by straight lines; members of the major magmatic series are connected by dotted lines; members of the minor magmatic series are connected by solid lines. 
consolidation. If this magma is a source of uranium, then the uranium deposits in the south-central part of the area may have originated fiom the biotite-quartz latite porphyry that crops out there.

The close geographic association of quartz bostonite with uraniumbearing veins in the Nigger Hill, Quartz Hill, and Lawson areas (Phair, 1952; Sims, 1956, p. 750; Sims and Tooker, 1956, p. 109; and Sims, Osterwald and Tooker, 1955, p. 18 and pl. 1) suggest that the magma that formed the quartz bostonite porphyry was by far the most important source of uranium mineralization. In the Central City district (Sims, 1956, p. 745 to 749), uranium deposits are closely related to the distribution of the quartz bostonite porphyry and are not related to the mineral zoning of the sulfide deposits That uranium is highly concentrated in the quartz bostonite porphyly of the Central City district is shown in figure 65 and by Phair (1952). A process by which the uranium is taken into solution by the aqueous phase is suggested by Phair (1952). These uranium-bearing solutions would move along fractures and contacts to the vein fissures and then to the sites of the uranium deposits.

\section{LITERATURE CITED}

Anderson, E M, 1942, The dynamics of faultıng London, Oliver \& Boyd

Bastın, E S, and Hill, J M, 1917, Economic geology of Gilpın County and adjacent parts of Clear Creek and Boulder Countres, Colo : US Geol Survey Prof Paper 94, 379 p

Faul, Henry, ed, 1954, Nucleaı geology New York, John Wlley \& Sons, 414 p

Gabriel, Alton, and Cox, E P, 1929, A staıning method for the quantitative deteımınation of ceitain rock mineials Am Mineıalogist, $v$ 14, p 290292

Harrison, J E, and Wells, J D, 1956, Geology and oie deposits of the Freeland-Lamaitine distıct, Clear Cieek County, Colo US Geol Survey Bull 1032-B, p 33-127

Harrison, J E, and Wells, J D, 1959, Geology and ore deposits of the Chicago Cieek area, Clear Creek County, Colo US Geol Survey P1 of Paper 319

Holmes, Aithur, 1946, The constıuction of a geological tıme-scale Geol Soc Glasgow Tians, $\mathrm{v} 21$, pt $1, \mathrm{p}$ 117-152

Loveııng, T S, and Goddard, E N, 1938, Laıamıde tgneous sequence and differentiation in the Fiont Range, Colo Geol Soc America Bull, v 49, p 35-68

Lovering, T S, and Goddaid, E N, 1950, Geology and ore deposits of the Fiont Range, Colo U S Geol Survey Prof Paper 223, 319 p

Phail, George, 1952, Radioactive Teitiary porphyries in the Central City distıct, Colorado, and their beaing upon pitchblende deposition, US Geol Survey TEI-247, issued by U S Atomic Energy Comm Tech Inf Seivice, Oak Ridge, Tenn

Russell, R D, 1935, Fiequency percentage determınatıons of detrital quaitz and feldspar Jour Sed Petrology, v 5, p 109-114

Sıms, P K, Oster wald, F W, and Tookeı, E W, 1955, Uranıum deposits in the Eureka Gulch area, Central City distıct, Gilpın County, Colo U S Geol Survey Bull 1032-A, p 1-31 
Sims, P K, and Tooker, E W, 1956, Pitchblende deposits in the Central City district and adjoining areas, Gilpin and Clear Creek Counties, Colo in Page, L R, Stocking, H E, and Smith, H B, Contributions to the geology of uranium and thorium by the United States Geological Survey and Atomic Energy Commission for the United Nations International Conference on Peaceful Uses of Atomic Energy, Geneva, Switzerland, 1955 U S Geol Survey Prof Paper 300, p 105-111

Sims, $P \mathrm{~K}, 1956$, The paragenesis and structure of pitchblende-bearing veins in the Central City district, Colorado Econ Geology, $v$ 51, p 739-756

Spurr, J E, Garrey, G H, and Ball, S H, 1908, Economic geology of the Georgetown quadrangle, Colorado US Geol Survey Prof Paper 63, 422 p Walker, $\mathbf{R}$ T, 1928, Mıneralized volcanıc explosion pıpes Eng and Mın Jour, v. 126 , p. $895-898,939-942$, and $976-984$ 


\section{INDEX}

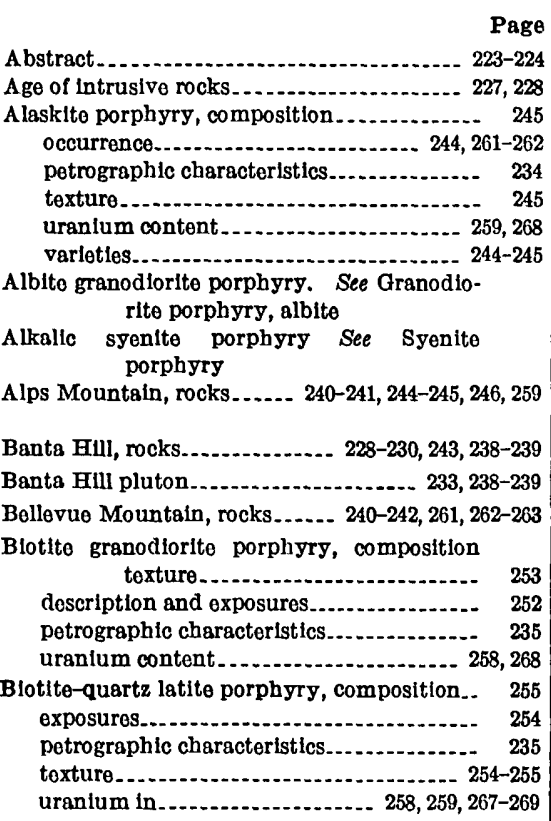

Biotite-quartz monzonite, uranium.

Biotite-quartz monzonite porphyry, composi-

tion...........................

exposure and description

petrographic characteristics.............. 253

Bostonite group, description ................. 245-250 histograms showing radioactivity....... 260, 261

Bostonite porphyry, composition ............. 247 description. ........................... 246-247 garnetlferous, composition.................. 248

description.............................. 247-248 occurrencos.......................... 246, 261 petrographic characteristics................ 235 quartz See Quartz, bostonite porphyry texture uranium.................................. 260, 268

Brocclas, intrusion of ....................... 263-264

Contral Oity, dikes near.... 233, 246, 249-250, 259, 262 rocks........................... 228-230, 262-263

Ohase Gulch

Chicago Oreek area, dikes ... $243,246,248,249-250,253,262$ rocks $228-230,249,250$

Clear Oreek, dikes near. $233,241,254$

Cottonwood Gulch, rocks
Dikes, alaskite porphyry biotite-quartz latite porphyry ............. 254 biotite-quartz monzonite porphyry....... 253 bostonite chilled borders of ........................ 230-231 granite porphyry in Gilson Gulch ......................... 237 in Prosser Gulch..................... 259, 267 mode of intrusion......................... 262-263 quartz bostonite.................... 249-250, 259 quartz monzonite . . . . . Dumont, rocks near........ 228-230, 246, 248, 253, 261 Elkhorn pluton. . . . . Equivalent uranium. . . . . .

Fall River, rocks................ 232, 240, 241, 252, 261

Fieldwork.................................. 226

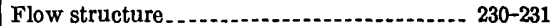

Front Range mineral belt.................. 225, 227

Gilson Gulch, dikes............. 233-234, 236, 237, 241 rocks of........................ 228-230, 233, 237

Gilson pluton.

Granite porphyry, composition............... 244 exposures................................. 243, 261 petrographic characteristics................ 234 texture.................................. 243-244 trachytic, composition..................... 249 exposures........................ 248, 261-262 petrographic characteristics............. 235

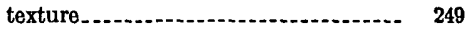
uranium............................ 260, 268 uranium.................................. 259, 268

Granodiorite group, light-colored, description_- 232-

histograms showing radioactivity.......- 258, 261

Granodiorite porphyry, albite, composition... 238 albite, exposures......................... 237 phenocrysts . . . . . texture............................... 238 uranium content.................... 258, 268 biotite, description......... 235, 252-253, 258, 268 hornblende, description............. 235, 251-252

light-colored, composition................. 237 phenocrysts...................... 234, 236 occurrence........................ 233, 261-262 texture............................... 236 petrographic characteristics.................. 234 Gregory Hill pluton.............. 233

Hornblende granodiorite group, description. 235, 251-255

histograms showing radioactivity....... 258, 261 
Hornblende granodiorite porphyry, accessory
minerals

Idaho Springs, rocks . . . . . . . . . . . . . ... 230, 233, 240-241, 243, 246, 253, 259, 261, 262-263

Igneous rocks See Intrusive rocks

Introduction.............................. 224-227

Intrusion, mode of ........................... 262-265

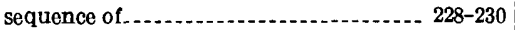

Intrusive rocks, alteration ................ 255 classification............................. 231-232

description................................ 232-255 differentiation of uranium and thorıum. 266-269 distribution............................... 261-262 form of .

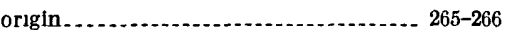
petrographic characterıstics, table...... 234-235 radioactıvity . . . . . . . . texture. . .

Joints. 230-231

Kings Flat

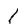
261

Lawson, dikes near 248,254

Leavenworth Gulch, rocks. $233,238-239$

Literature cited 269-270

Location of the area. 224,225

Mapping

Maryland Mountain

Mill Creek. $259,261,267,269$

Nigger Hill 265-266
Petrographic studıes, basıs for classification.... 231 characteristics of igneous rocks.......... 234-235 scope..................................... 226-227 procedures................................. 231

Pewabic Mountain, dikes near............. 248, 261

Plutons . .. 228, 233, 237, 241, 244, 246, 251, 252, 262-263,

Prosser Gulch, uranium deposits. . . . . ....... 259, 267

Quartz bostonite porphyı y, composition...... 250 occurrence.............................. 249-250, 261

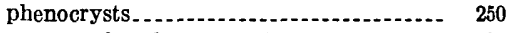

petrographic characteristics.............. 235 radioactivity of.......... 257, 260, 261, 267, 268, 269 texture................................ 250

Quartz Hill, rocks.............. 228-230, 261, 263, 269

Quartz monzonite group, descrıption ....... 240-245 histograms showing radioactivity ....... 259, 260

Quartz monzonite porphyry, composition.... 240 occurrences........................ 240-241, 261 phases............................... 240, 241-242

phenocrysts........................... 241-242 uranium

Russell Gulch, rocks. . _................. 233, 239

Spring Gulch, rocks in $228-230,246,248,249-250,252$ Sun and Moon pluton..................... 237, 238

Syenite porphyry, alkalic, composition....... 239

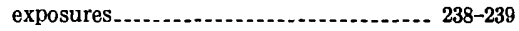
petrographic characterıstics............... 234 phenocrysts. .......................... 234, 239 texture............. 239 uranium .................................... 258, 268

Tertiary igneous rocks...................... 227-228

The Patch .... . . .

Trachytic granite porphyry See Granite porphyry, trachytic

Trail Creek......... 233, 241-242, 248, 249-250, 259, 261

Uranium, differentiation of................. 266-269 content in rock of the area . ............. 257-260

243 